\title{
Transgene Expression in Microalgae-From Tools to Applications
}

\author{
Lior Doron ${ }^{\dagger}, \mathrm{Na}^{\prime}$ ama Segal ${ }^{\dagger}$ and Michal Shapira * \\ Department of Life Sciences, Ben-Gurion University of the Negev, Beer Sheva, Israel
}

\section{OPEN ACCESS}

Edited by:

Steven James Burgess, University of Cambridge, UK

Reviewed by:

Ralf Alexander Wilhelm, Julius Kühn-Institut, Germany Katrin Geisler,

University of Cambridge, UK

*Correspondence: Michal Shapira shapiram@bgu.ac.il

${ }^{\dagger}$ These authors have contributed equally to this work.

Specialty section: This article was submitted to

Plant Biotechnology, a section of the journal Frontiers in Plant Science

Received: 12 November 2015 Accepted: 29 March 2016

Published: 22 April 2016

Citation:

Doron L, Segal N and Shapira M (2016) Transgene Expression in

Microalgae-From Tools to Applications. Front. Plant Sci. 7:505. doi: 10.3389/fpls.2016.00505
Microalgae comprise a biodiverse group of photosynthetic organisms that reside in water sources and sediments. The green microalgae Chlamydomonas reinhardtii was adopted as a useful model organism for studying various physiological systems. Its ability to grow under both photosynthetic and heterotrophic conditions allows efficient growth of non-photosynthetic mutants, making Chlamydomonas a useful genetic tool to study photosynthesis. In addition, this green alga can grow as haploid or diploid cells, similar to yeast, providing a powerful genetic system. As a result, easy and efficient transformation systems have been developed for Chlamydomonas, targeting both the chloroplast and nuclear genomes. Since microalgae comprise a rich repertoire of species that offer variable advantages for biotech and biomed industries, gene transfer technologies were further developed for many microalgae to allow for the expression of foreign proteins of interest. Expressing foreign genes in the chloroplast enables the targeting of foreign DNA to specific sites by homologous recombination. Chloroplast transformation also allows for the introduction of genes encoding several enzymes from a complex pathway, possibly as an operon. Expressing foreign proteins in the chloroplast can also be achieved by introducing the target gene into the nuclear genome, with the protein product bearing a targeting signal that directs import of the transgene-product into the chloroplast, like other endogenous chloroplast proteins. Integration of foreign genes into the nuclear genome is mostly random, resulting in large variability between different clones, such that extensive screening is required. The use of different selection modalities is also described, with special emphasis on the use of herbicides and metabolic markers which are considered to be friendly to the environment, as compared to drug-resistance genes that are commonly used. Finally, despite the development of a wide range of transformation tools and approaches, expression of foreign genes in microalgae suffers from low efficiency. Thus, novel tools have appeared in recent years to deal with this problem. Finally, while $C$. reinhardtii was traditionally used as a model organism for the development of transformation systems and their subsequent improvement, similar technologies can be adapted for other microalgae that may have higher biotechnological value.

Keywords: Chlamydomonas, chloroplast transformation of algae, diatoms, microalgae, nuclear transformation of algae, red microalgae, selection markers 


\section{INTRODUCTION}

Microalgae first attracted the attention of the biotech industry several decades ago as a potential platform for extracting natural products, with further improvements in their production relying on advanced technologies. Microalgae provide a manufacturing platform for the expression of foreign genes due to their quick growth under photoautotrophic conditions and their low cost of maintenance, as compared to land plants, mammalian cells, yeast, and bacteria. In addition, many algal species have developed unique metabolic pathways that produce compounds of commercial value (Priyadarshani and Rath, 2012; Rasala and Mayfield, 2014). Certain algal species, such as Dunaliella, are adapted for growth under extreme conditions, in this case high salinity (Ben-Amotz and Avron, 1972), thereby reducing the risk of contamination.

The plethora of high-value chemicals that can be extracted from both cyanobacteria and eukaryote microalgae include compounds used in the food industry, medicine, and cosmetics. The possibility of advancing the use of microalgae for future development of biofuel production and additional healthrelated products has also been examined. Microalgae have been exploited for the production of food additives, such as $\beta$-carotene (Varela et al., 2015) and astaxanthine, as well as long-chain polyunsaturated fatty acids (PUFAs; Borowitzka, 2013; SharonGojman et al., 2015). Another line of industrial exploitation makes use of cell-wall sulfated polysaccharides, mainly for the cosmetics industry (Arad and Levy-Ontman, 2010). However, competition from cheaper parallel compounds extracted from macroalgae reveals the need for improvements to microlalgal systems. Efforts have long been directed at the industrial use of microalgal biomass for biofuel production, although the relatively high cost and low yield are of concern. Thus, biotechnological improvements combined with global market changes may, however, have major implications for the future use of microalgae as a biofuel source. Algae can also contribute in the development of novel and sensitive biosensors for environmental uses, such as monitoring pollutants in soil and water sources (Viji et al., 2014; Diaz et al., 2015). Finally, algae are an important component of the marine aquaculture, and can be used in ecological reef rehabilitation, especially in view of their ability to form symbiontic relationships with coral (Hagedorn and Carter, 2015).

Heterotrophic growth of microalgae is usually limited to bioreactors, whereas photoautotrophic growth can be carried out in open ponds. Still, the use of open ponds is restricted to extreme conditions (salt, temperature, $\mathrm{pH}$ ) that allow exclusive growth of the organism of interest and avoid contamination by opportunistic organisms. This has been shown for Dunaliella, which is adopted to grow at high salt concentrations (Ben-Amotz and Avron, 1983), as well as for Spirulina, a photoautotrophic cyanobacteria that grows at high pH (Nolla-Ardevol et al., 2015).

In view of the above, genetic manipulations of microalga can lead to major changes in microalgal biotechnologybased industries. Such manipulations include the transfer of biosynthetic cascades into organisms that are suitable for growth in open ponds, or alternatively, adapting organisms that produce compounds of interest to grow under extreme conditions, thus reducing the risk of contamination. Recent developments in genome sequencing, combined with old and new systems for genetic manipulation, act synergistically to advance all aspects of microalgal research, both basic and applied. This review focuses on available systems and approaches for genetic manipulation of the chloroplast and nuclear genomes of microalgae, addressing unsolved issues, as well as points that await improvement.

Significant efforts have been invested in establishing tools that will allow for realization of the promise that algae hold for the production of high value bio-products, with most such tools having been originally developed for the model alga Chlamydomonas reinhardtii (Kindle et al., 1989). Transgene expression in Chlamydomonas was based on the accumulated identification of regulatory elements, such as promoters and untranslated regions (UTRs; Harris, 2009). Subsequently, successful nuclear transformation systems were also developed for $\sim 25$ microalgae species (see Tables 1, 2). In many cases, microalgal transformation resulted in stable expression of transgenes from either the nuclear or plastid genomes. The large amount of genomic and EST data from different algae contribute to the rich molecular toolbox currently available.

\section{CHLOROPLAST TRANSFORMATION SYSTEMS}

\section{Technical Approaches Used for Chloroplast Transformation}

Although stable transformation of microalgae was first developed for the chloroplast of $C$. reinhardtii, there are still fewer transformation systems that target the chloroplast, as compared to those targeting the microalgal nucleus. One great advantage of chloroplast transformation is that transgenes can be easily directed to integrate via homologous recombination, whereas nuclear transformation of microalgae usually results in random integration events. The development of the CRISPR-CAS9 system in microalgae may offer a solution for targeting transgenes into specific sites in the nuclear genome. The improvement of chloroplast transformation tools is also a dynamic field, as discussed elsewhere for microalgae (Purton, 2007; Purton et al., 2013) and higher plants (Bock, 2015).

The first stable transformation system for the chloroplast of $C$. reinhardtii was established using biolistic delivery. The foreign DNA was designed to rescue three mutants of the chloroplast $a t p B$ gene by homologous recombination of the transgenic marker into the target mutant strain and restore photosynthetic activity (Boynton et al., 1988). It was further shown that Chlamydomonas chloroplast transformation could be achieved by agitating cell wall-deficient cells with the DNA of interest in the presence of glass beads (Kindle et al., 1991; Economou et al., 2014; Rochaix et al., 2014). A chloroplast transformation system that was based on integration into the inverted repeat of the plastid genome using electroporation was also developed for Phaeodactylum tricornutum (Xie et al., 2014). Thus, similar technologies can be used for both chloroplast and 
TABLE 1 | List of selection markers and selection modes for chloroplast transformation.

\begin{tabular}{|c|c|c|c|c|c|}
\hline Type of selection marker & Selection gene & Gene product & Selection mode & $\begin{array}{l}\text { Species/Genetic } \\
\text { background }\end{array}$ & References \\
\hline \multirow[t]{7}{*}{ Antibiotic resistance } & aadA & $\begin{array}{l}\text { Aminoglycoside } \\
3^{\prime} \text { adenylyltransferase }\end{array}$ & $\begin{array}{l}\text { Resistance to } \\
\text { Spectinomycin/Streptomycin }\end{array}$ & $\begin{array}{l}\text { Chlamydomonas } \\
\text { reinhardtii }\end{array}$ & $\begin{array}{l}\text { Goldschmidt- } \\
\text { Clermont, } \\
1991\end{array}$ \\
\hline & & & & Euglena gracilis & $\begin{array}{l}\text { Doetsch et al., } \\
2001\end{array}$ \\
\hline & & & & $\begin{array}{l}\text { Haematococcus } \\
\text { pluvialis }\end{array}$ & $\begin{array}{l}\text { Gutiérrez et al., } \\
2012\end{array}$ \\
\hline & aphA6 & $\begin{array}{l}\text { Aminoglycoside } \\
3^{\prime} \text { - transferase }\end{array}$ & $\begin{array}{l}\text { Resistance to } \\
\text { Kanamycin }\end{array}$ & $\begin{array}{l}\text { Chlamydomonas } \\
\text { reinhardtii }\end{array}$ & $\begin{array}{l}\text { Bateman and } \\
\text { Purton, } 2000\end{array}$ \\
\hline & ere $B$ & $\begin{array}{l}\text { Erythromycin } \\
\text { esterase }\end{array}$ & $\begin{array}{l}\text { Resistance to } \\
\text { Erythromycin }\end{array}$ & $\begin{array}{l}\text { Dunaliella } \\
\text { tertiolecta }\end{array}$ & $\begin{array}{l}\text { Georgianna et al., } \\
2013\end{array}$ \\
\hline & rrnS and $r r n L$ point mutation & $16 S$ and $23 S$ & $\begin{array}{l}\text { Resistance to } \\
\text { Spectinomycin, } \\
\text { Streptomycin, } \\
\text { Kanamycin and } \\
\text { Erythromycin }\end{array}$ & $\begin{array}{l}\text { Chlamydomonas } \\
\text { reinhardtii }\end{array}$ & $\begin{array}{l}\text { Newman et al., } \\
1990\end{array}$ \\
\hline & Cat & $\begin{array}{l}\text { Chloramphenicol } \\
\text { acetyltransferase }\end{array}$ & $\begin{array}{l}\text { Resistance to } \\
\text { Chloramphenicol }\end{array}$ & $\begin{array}{l}\text { Phaeodactylum } \\
\text { tricornutum }\end{array}$ & Xie et al., 2014 \\
\hline \multirow[t]{4}{*}{ Herbicide resistance } & psbA mutant & $\begin{array}{l}\text { Photosystem II } \\
\text { protein D1 }\end{array}$ & $\begin{array}{l}\text { Resistance to } \\
\text { 3-(3,4-Dichlorophenyl)- } \\
\text { 1,1-dimethylurea } \\
\text { (DCMU) }\end{array}$ & $\begin{array}{l}\text { Chlamydomonas } \\
\text { reinhardtii }\end{array}$ & $\begin{array}{l}\text { Przibilla et al., } \\
\text { 1991; Newman } \\
\text { et al., } 1992\end{array}$ \\
\hline & ahas(W492S) & $\begin{array}{l}\text { Acetohydroxyacid } \\
\text { synthase }\end{array}$ & $\begin{array}{l}\text { Resistance to } \\
\text { Sulfometuron methyl }\end{array}$ & Porphyridium sp. & $\begin{array}{l}\text { Lapidot et al., } \\
\text { 1999, } 2002\end{array}$ \\
\hline & & & & $\begin{array}{l}\text { Parietochloris } \\
\text { incisa }\end{array}$ & $\begin{array}{l}\text { Grundman et al., } \\
2012\end{array}$ \\
\hline & Bar & $\begin{array}{l}\text { Phosphinothricin } \\
\text { acetyltransferase }\end{array}$ & $\begin{array}{l}\text { Tolerance to } \\
\text { Glufosinate, or its } \\
\text { ammonium salt DL- } \\
\text { Phosphinothricin }\end{array}$ & $\begin{array}{l}\text { Platymonas } \\
\text { subcordiformis }\end{array}$ & Cui et al., 2014 \\
\hline \multirow[t]{5}{*}{ Metabolic markers } & $\operatorname{atp} B$ & $\begin{array}{l}\beta \text { subunit of ATP } \\
\text { synthase }\end{array}$ & $\begin{array}{l}\text { Photoautotrophic } \\
\text { growth }\end{array}$ & $\begin{array}{l}\text { Chlamydomonas } \\
\text { reinhardtii cc-373 } \\
\text { (atpB-) }\end{array}$ & $\begin{array}{l}\text { Boynton et al., } \\
1988\end{array}$ \\
\hline & nifH & $\beta$-glucuronidase & $\begin{array}{l}\text { Photoautotrophic } \\
\text { growth }\end{array}$ & $\begin{array}{l}\text { Chlamydomonas } \\
\text { reinhardtii (chlL-) }\end{array}$ & Cheng et al., 2005 \\
\hline & $p s b A$ & $\begin{array}{l}\text { Photosystem II } \\
\text { protein D1 }\end{array}$ & $\begin{array}{l}\text { Photoautotrophic } \\
\text { growth }\end{array}$ & $\begin{array}{l}\text { Chlamydomonas } \\
\text { reinhardtii FUD7 }\end{array}$ & $\begin{array}{l}\text { Michelet et al., } \\
2011\end{array}$ \\
\hline & tsc $A$ & $\begin{array}{l}\text { Small RNA that } \\
\text { participates in } \\
\text { trans-splicing of } \\
\text { the psaA transcript }\end{array}$ & $\begin{array}{l}\text { Photoautotrophic } \\
\text { growth }\end{array}$ & $\begin{array}{l}\text { Chlamydomonas } \\
\text { reinhardtii (tscA-) }\end{array}$ & $\begin{array}{l}\text { Goldschmidt- } \\
\text { Clermont, 1991; } \\
\text { Kindle et al., } 1991\end{array}$ \\
\hline & $\arg 9$ & $\begin{array}{l}\text { Acetylornithine } \\
\text { aminotransferase }\end{array}$ & Arginine free media & $\begin{array}{l}\text { Chlamydomonas } \\
\text { reinhardtii (arg9-) }\end{array}$ & $\begin{array}{l}\text { Remacle et al., } \\
2009\end{array}$ \\
\hline
\end{tabular}

nuclear transformations. The various markers for chloroplast transformation systems available today are summarized in Table 1.

\section{Selection Systems}

\section{Selection Markers for Chloroplast Transformation Based on Photoautotrophic Growth}

Chlamydomonas offers the advantage of being able to grow under non-photosynthetic conditions, using acetate as a carbon energy source. Thus, using non-photosynthetic mutants as recipient strains and recovery of their photosynthetic activity as a reporter system was used for reconstituting expression of the mutated atpB gene, encoding for ATP synthase (Boynton et al., 1988), and the $t s c A$ gene, encoding a small RNA that participates in transsplicing of the psaA transcript (Goldschmidt-Clermont, 1991; Kindle et al., 1991).

Marker rotation is an approach that was originally aimed at examining whether the bacterial nifH gene from Klebsiella pneumoniae could replace the algal ChlL gene, which is responsible for chlorophyll biosynthesis in the dark. Both 
TABLE 2 | Commonly used nuclear control elements for constitutive or inducible transgene expression.

\begin{tabular}{lllll}
\hline $\begin{array}{l}\text { Functional } \\
\text { elements }\end{array}$ & $\begin{array}{l}\text { Originally controlling } \\
\text { expression of }\end{array}$ & Property & Source of element & Comments \\
\hline CaMV35S promoter & $\begin{array}{l}35 S \text { Viral protein from } \\
\text { the Cauliflower mosaic } \\
\text { virus }\end{array}$ & $\begin{array}{l}\text { Strong heterologous } \\
\text { constitutive promoter } \\
\text { which functions well in } \\
\text { land plants and some } \\
\text { algae species }\end{array}$ & $\begin{array}{l}\text { Cauliflower mosaic } \\
\text { virus }\end{array}$ & $\begin{array}{l}\text { Contradictory data for } \\
\text { Chlamydomonas }\end{array}$ \\
& &
\end{tabular}

High efficiency for different Chlorella species, Dunalliela, diatoms, Haematoccoccus and Nanochloropsis

\section{Algal species used with this} control element

Chlamydomonas reinhardtii, Successful transformation: (Kumar et al., 2004)

Unsuccessful transformation: (Day et al., 1990; Diaz-Santos et al., 2013)

Chlorella kessleri, (El-Sheekh, 1999)

Chlorella ellipsoidea, (Jarvis and Brown, 1991)

Chlorella vulgaris, (Chow and Tung, 1999; Wang C. et al., 2007; Cha et al., 2012)

Dunaliella salina (Tan et al., 2005) Amphidinium sp. and Symbiodinium microadriaticum, (ten Lohuis and Miller, 1998)

Phaeodactylum tricornutum, (Sakaue et al., 2008)

Haematococcus pluvialis, (Kathiresan et al., 2015)

Nannochloropsis sp., (Cha et al., 2011)

$\begin{array}{llll}\text { RBCS2 promoter } & \begin{array}{l}\text { Small subunit of the } \\ \text { ribulose bisphosphate }\end{array} & \begin{array}{l}\text { Strong endogenous } \\ \text { constitutive promoter }\end{array} & \begin{array}{l}\text { Chlamydomonas } \\ \text { reinhardtii }\end{array}\end{array}$
carboxylase
Introducing the first intron of $R B C S 2$ into the coding region or fusing the HSP70A promoter upstream to the RBCS2 promoter greatly improves the expression of transgenes

Dunaliella salina

Dunaliella tertiolecta

Lobosphaera (Parietochloris) incisa

Adding a nuclear matrix attachment regions (MAR) before the promoter region and after the terminator sequence was shown to increase transgene expression

Only one transgenic line was recovered when used to transform Dunaliella tertiolecta

The upstream region of the Lobosphaera incisa
Chlamydomonas reinhardtii, (Stevens et al., 1996; Lumbreras et al., 1998; Fuhrmann et al., 1999; Schroda et al., 2000)

Dunaliella salina, (Sun et al., 2005)

Chlorella ellipsoidea, (Kim et al., 2002) Volvox carteri, (Hallmann and Wodniok, 2006)

Pseudochoricystis ellipsoidea, (Imamura et al., 2012)

Nannochloropsis sp., (Chen et al., 2008; Li and Tsai, 2009)

Dunaliella salina (Wang T. Y. et al., 2007)

Chlamydomonas reinhardtii, (Walker et al., 2005a)

Dunaliella tertiolecta, (Walker et al., 2005b) RBCS promoter (ranging from -1000 to -450 ) contains elements counteracting transformation or gene expression
Chlamydomonas reinhardtii, (Zorin et al., 2014)

Lobosphaera (Parietochloris) incise (Zorin et al., 2014) 
TABLE 2 | Continued

\begin{tabular}{|c|c|c|c|c|c|}
\hline $\begin{array}{l}\text { Functional } \\
\text { elements }\end{array}$ & $\begin{array}{l}\text { Originally controlling } \\
\text { expression of }\end{array}$ & Property & Source of element & Comments & $\begin{array}{l}\text { Algal species used with this } \\
\text { control element }\end{array}$ \\
\hline PSAD promoter & $\begin{array}{l}\text { An abundant } \\
\text { chloroplast protein of } \\
\text { Photosystem I } \\
\text { complex, encoded by } \\
\text { the nuclear genome }\end{array}$ & $\begin{array}{l}\text { A strong endogenous } \\
\text { constitutive promoter }\end{array}$ & $\begin{array}{l}\text { Chlamydomonas } \\
\text { reinhardtii }\end{array}$ & $\begin{array}{l}\text { Expression driven by the } \\
P S A D \text { promoter can be } \\
\text { enhanced by high light }\end{array}$ & $\begin{array}{l}\text { Chlamydomonas reinhardtii, (Fischer } \\
\text { and Rochaix, 2001) }\end{array}$ \\
\hline \multirow[t]{3}{*}{ FCP promoter } & \multirow[t]{3}{*}{$\begin{array}{l}\text { Fucoxanthin- } \\
\text { chlorophyll binding } \\
\text { protein of the } \\
\text { light-harvesting } \\
\text { antennae complexes }\end{array}$} & \multirow[t]{3}{*}{$\begin{array}{l}\text { Strong Endogenous } \\
\text { and constitutive } \\
\text { promoter }\end{array}$} & $\begin{array}{l}\text { Phaeodactylum } \\
\text { tricornutum }\end{array}$ & \multirow[t]{2}{*}{$\begin{array}{l}\text { FCP promoters (A-E) are } \\
\text { capable of driving } \\
\text { expression of the bacterial } \\
\text { ble gene at levels } \\
\text { sufficient to confer } \\
\text { resistance to Zeocin }\end{array}$} & $\begin{array}{l}\text { Phaeodactylum tricornutum, (Apt } \\
\text { et al., 1996; Falciatore et al., 1999; } \\
\text { Zaslavskaia et al., 2000; Kilian and } \\
\text { Kroth, 2005) } \\
\text { Thalassiosira weissflogii, (Falciatore } \\
\text { et al., 1999) }\end{array}$ \\
\hline & & & \multirow[t]{2}{*}{$\begin{array}{l}\text { Cylindrotheca } \\
\text { fusiformis }\end{array}$} & & $\begin{array}{l}\text { Cylindrotheca fusiformis, (Poulsen } \\
\text { and Kroger, 2005) }\end{array}$ \\
\hline & & & & $\begin{array}{l}\text { Thalassiosira pseudonana } \\
\text { The transformation of } \\
\text { Cylindrotheca fusiformis } \\
\text { using a pFCP-based } \\
\text { vector improved the } \\
\text { transformation efficiency } \\
\text { about four fold as } \\
\text { compared to the } \\
\text { P } \delta \text {-containing vectors }\end{array}$ & $\begin{array}{l}\text { Thalassiosira pseudonana, (Poulsen } \\
\text { et al., 2006) }\end{array}$ \\
\hline P $\delta$ & $\begin{array}{l}\varepsilon \text { Frustulin-member of } \\
\text { the calcium-binding } \\
\text { glycoproteins }\end{array}$ & $\begin{array}{l}\text { Endogenous } \\
\text { constitutive promoter }\end{array}$ & $\begin{array}{l}\text { Cylindrotheca } \\
\text { fusiformis }\end{array}$ & $\begin{array}{l}\text { Used to drive functional } \\
\text { expression of a } \\
\text { membrane protein }\end{array}$ & $\begin{array}{l}\text { Cylindrotheca fusiformis, (Fischer } \\
\text { et al., 1999) }\end{array}$ \\
\hline \multirow[t]{2}{*}{ Ubi1- $\Omega$ promoter } & \multirow{2}{*}{$\begin{array}{l}\text { Ubiquitin promoter } \\
\text { fused with the } \\
\text { TMV-omega translation } \\
\text { enhancer element }\end{array}$} & \multirow[t]{2}{*}{$\begin{array}{l}\text { Strong heterologous } \\
\text { constitutive promoter }\end{array}$} & \multirow[t]{2}{*}{ Zea maize } & \multirow{2}{*}{$\begin{array}{l}\text { Highly efficient for } \\
\text { transformation of Chlorella } \\
\text { ellipsoidea and Dunaliella } \\
\text { salina cells }\end{array}$} & $\begin{array}{l}\text { Chlorella ellipsoidea, (Chen et al., } \\
\text { 2001) }\end{array}$ \\
\hline & & & & & $\begin{array}{l}\text { Dunaliella salina, (Geng et al., 2003, } \\
\text { 2004) }\end{array}$ \\
\hline GAPDH & $\begin{array}{l}\text { Glyceraldehyde } \\
\text {-3-phosphate } \\
\text { dehydrogenase }\end{array}$ & $\begin{array}{l}\text { Endogenous } \\
\text { constitutive promoter }\end{array}$ & Dunaliella salina & $\begin{array}{l}\text { Used to drive expression } \\
\text { of the heterologous gene } \\
\text { encoding bialaphos } \\
\text { resistance (bar) and of the } \\
N \text {-terminal fragment of } \\
\text { human canstatin }\end{array}$ & Dunaliella salina, (Jia et al., 2012) \\
\hline$C A B \| l-1$ & $\begin{array}{l}\text { Light-harvesting } \\
\text { chlorophyll a/b-binding } \\
\text { proteins of } \\
\text { photosystem II }\end{array}$ & Endogenous promoter & $\begin{array}{l}\text { Chlamydomonas } \\
\text { reinhardtii }\end{array}$ & $\begin{array}{l}\text { The NIT1 gene expressed } \\
\text { under the control of the } \\
\text { CABII-1 promoter was } \\
\text { highly stimulated by light }\end{array}$ & $\begin{array}{l}\text { Chlamydomonas reinhardtii, } \\
\text { (Blankenship and Kindle, 1992) }\end{array}$ \\
\hline \multirow[t]{6}{*}{ NIT1 } & \multirow[t]{6}{*}{$\begin{array}{l}\text { Nitrate reductase } \\
\text { promoter }\end{array}$} & \multirow[t]{6}{*}{$\begin{array}{l}\text { Strong inducible } \\
\text { endogenous promoter }\end{array}$} & $\begin{array}{l}\text { Chlamydomonas } \\
\text { reinhardt }\end{array}$ & \multirow{6}{*}{$\begin{array}{l}\text { Expression of the nitrate } \\
\text { reductase is switched off } \\
\text { when cells are grown in } \\
\text { the presence of } \\
\text { ammonium ions and } \\
\text { becomes switched on } \\
\text { within } 4 \mathrm{~h} \text { when cells are } \\
\text { transferred to a medium } \\
\text { containing nitrate. An } \\
\text { expression vector with the } \\
\text { NIT1 promoter is widely } \\
\text { used in many studies }\end{array}$} & $\begin{array}{l}\text { Chlamydomonas reinhardtii, } \\
\text { (Ohresser et al., 1997; Koblenz and } \\
\text { Lechtreck, 2005; Schmollinger et al., } \\
\text { 2010) } \\
\text { Chlorella ellipsoidea, (Wang et al., } \\
\text { 2004) }\end{array}$ \\
\hline & & & $\begin{array}{l}\text { Phaeodactylum } \\
\text { tricornutum }\end{array}$ & & $\begin{array}{l}\text { Phaeodactylum tricornutum, (Niu } \\
\text { et al., 2012); Chlorella vulgaris, (Niu } \\
\text { et al., 2011) }\end{array}$ \\
\hline & & & Dunaliella salina & & Dunaliella salina, (Li et al., 2007, 2008) \\
\hline & & & $\begin{array}{l}\text { Cylindrotheca } \\
\text { fusiformis }\end{array}$ & & $\begin{array}{l}\text { Cylindrotheca fusiformis, (Poulsen } \\
\text { and Kroger, 2005); Phaeodactylum } \\
\text { tricornutum, (Miyagawa et al., 2009) }\end{array}$ \\
\hline & & & $\begin{array}{l}\text { Thalassiosira } \\
\text { pseudonana }\end{array}$ & & $\begin{array}{l}\text { Thalassiosira pseudonana, (Poulsen } \\
\text { et al., 2006) }\end{array}$ \\
\hline & & & Volvox carteri & & $\begin{array}{l}\text { Volvox carteri, (von der Heyde et al., } \\
\text { 2015) }\end{array}$ \\
\hline
\end{tabular}


TABLE 2 | Continued

\begin{tabular}{|c|c|c|c|c|c|}
\hline $\begin{array}{l}\text { Functional } \\
\text { elements }\end{array}$ & $\begin{array}{l}\text { Originally controlling } \\
\text { expression of }\end{array}$ & Property & Source of element & Comments & $\begin{array}{l}\text { Algal species used with this } \\
\text { control element }\end{array}$ \\
\hline LIP & Light-induced protein & & Dunaliella sp. & $\begin{array}{l}\text { The LIP promoter can be } \\
\text { used for conditional gene } \\
\text { expression in response to } \\
\text { high light }\end{array}$ & $\begin{array}{l}\text { Chlamydomonas reinhardtii, (Park } \\
\text { et al., 2013; Baek et al., 2016) }\end{array}$ \\
\hline $\begin{array}{l}\text { B12-responsive } \\
\text { element }\end{array}$ & $\begin{array}{l}\text { B12-independent } \\
\text { methionine synthase } \\
\text { (METE) }\end{array}$ & & $\begin{array}{l}\text { Chlamydomonas } \\
\text { reinhardtii }\end{array}$ & $\begin{array}{l}\text { The B12-responsive } \\
\text { element can repress } \\
\text { expression of a reporter } \\
\text { gene following the } \\
\text { addition of } B_{12}\end{array}$ & $\begin{array}{l}\text { Chlamydomonas reinhardtii, (Helliwell } \\
\text { et al., 2014) }\end{array}$ \\
\hline TPP riboswitch & $\begin{array}{l}\text { Thiamine } \\
\text { pyrophosphate (TPP) }\end{array}$ & $\begin{array}{l}\text { A riboswitch-regulated } \\
\text { element based on the } \\
\text { thiamine } \\
\text { pyrophosphate }\end{array}$ & $\begin{array}{l}\text { Chlamydomonas } \\
\text { reinhardtii }\end{array}$ & $\begin{array}{l}\text { The TPP riboswitch } \\
\text { regulates expression in } \\
\text { response to the presence } \\
\text { or absence of TPP in the } \\
\text { growth medium }\end{array}$ & $\begin{array}{l}\text { Chlamydomonas reinhardtii, } \\
\text { (Ramundo et al., 2013) }\end{array}$ \\
\hline CYC6 promoter & Cytochrome c6 & $\begin{array}{l}\text { An inducible } \\
\text { endogenous promoter }\end{array}$ & & $\begin{array}{l}\text { Metal-responsive element } \\
\text { that is responsive to both } \\
\text { nickel and cobalt ions and } \\
\text { could be inhibited by } \\
\text { EDTA }\end{array}$ & $\begin{array}{l}\text { Chlamydomonas reinhardtii, (Quinn } \\
\text { and Merchant, 1995) }\end{array}$ \\
\hline
\end{tabular}

genes show a remarkable similarity in their domain structure, suggesting that nifH could replace ChlL for binding to a $[4 \mathrm{Fe}-$ $4 \mathrm{~S}$ ] cluster, thereby directly introducing the nitrogenase $\mathrm{Fe}$ protein into the Chlamydomonas plastome. In addition to using this approach for investigating the nitrogenase-like complex in the chloroplast, it could serve as a platform for plastid engineering into a functional nitrogenase-containing organelle. Accordingly, petB (cytochrome b6) was initially replaced by the selection marker aadA, and non-photosynthetic transformants were selected. A second round of transformation with the mutant strain restored the pet $B$ gene product and, moreover, introduced nifH (or uidA, encoding $\beta$-glucuronidase), allowing selection based on the ability to grow under photoautotrophic conditions (Cheng et al., 2005).

The use of FUD7 as a recipient strain offered a selection mechanism based on the ability of the transformed algae to grow under photoautotrophic conditions. FUD7 is a mutant that carries a deletion between exon 1 of $p s b A$ and the $5 S$ gene. Thus, a cassette that reinstalls the open reading frame of $p s b A$, along with a tagged gene of interest flanked by $3^{\prime}$ UTR sequences, was established (Michelet et al., 2011).

\section{Selection Markers for Chloroplast Transformation Based on Metabolic Enzymes}

Metabolic selection of transformed cells provides a great advantage over the use of genes encoding for resistance to antibiotics and herbicides, as metabolic selection is considered to be more environmental friendly. Metabolic selection is common in yeast and animal cells, especially since many markers offer positive and negative selections. For instance, acetylornithine aminotransferase (ARG9) is a key enzyme in the metabolic pathway of arginine. It is encoded in the nucleus of C. reinhardtii, with the protein translocating into the chloroplast. A mutation in $A R G 9$ resulted in an auxotrophic phenotype, such that the algal cells could only grow if arginine was added to the medium. The Arabidopsis thaliana ARG9 gene, known for its high A/T content that is typical of the chloroplast genome (Nakamura et al., 2000), was expressed in the plastid of a Chlamydomonas mutant strain that was originally deficient of ARG9 expression. The foreign $A R G 9$ gene, now encoded by the chloroplast genome, was able to rescue the auxotrophic phenotype and restore arginine synthesis. This elegant approach created a metabolic selection system for chloroplast transformation in Chlamydomonas (Remacle et al., 2009).

\section{Selection Markers for Chloroplast Transformation Based on Resistance to Antibiotics}

Mutations in the sequence of the 16S ( $r r n S)$ and 23S ( $r r n L)$ rRNA that confer resistance to spectinomycin, streptomycin, kanamycin and erythromycin in C. reinhardtii (Harris et al., 1989) were previously used to establish an antibiotic-based selective marker that exchanged wild type RNA with the gene encoding resistant RNA (Newman et al., 1990). Later, resistance to spectinomycin was conferred by introducing the bacterialderived aadA gene into the chloroplast genome, encoding aminoglycoside $3^{\prime}$ adenyl transferase. This gene is still the most frequently used marker for chloroplast transformations in algae and higher plants. The aadA-rbcL expression cassette was adapted and used to transform the genome of the Haematococcus pluvialis chloroplast (Gutiérrez et al., 2012).

An additional bacterial gene, aphA6, encoding aminoglycoside $\left(3^{\prime}\right)$ transferase that confers resistance to aminoglycoside antibiotics was used with Chlamydomnas reinhardtii. The combination of aadA with aphA6 extended 
the possibility for expressing multiple foreign genes in the chloroplast (Bateman and Purton, 2000). In 2013, the group of Stephan Mayfield constructed a cassette for Dunaliella tertiolecta chloroplast transformation. The construct that encodes both the gene of interest and the erythromycin esterase gene, ereB, was successfully introduced into $D$. tertiolecta cells via particle bombardment (Georgianna et al., 2013). A chloroplast-based expression system developed for the diatom $P$. tricornutum uses the chloramphenicol acetyltransferase (CAT) gene as a selection marker, as it confers resistance to chloramphenicol. This cassette promoted the expression of a foreign gene, along with the selection marker (Xie et al., 2014).

Finally, there is a strong demand for marker removal systems due to biotechnological concerns and commercial requests. Such a system was first established for Chlamydomonas by designing a dedicated cassette for promoting a recombination event that allows for removal of the selection marker, once the selection pressure is removed. The additional foreign gene in this cassette was maintained in the genome despite the removal of the selection gene marker because it was located outside of the sequence repeats that drive the recombination event (Fischer et al., 1996).

\section{Selection Markers for Chloroplast Transformation Based on Resistance to Herbicides}

A mutation in the fifth exon of the $p s b A$ coding region conferred resistance of Chlamydomonas cells to 3-(3,4-dichlorophenyl)1,1-dimethylurea (DCMU), a herbicide that blocks the electron transfer pathway in PSII. Thus, DCMU resistance was initially used as a selection marker for understanding the occurrence of integration hotspots in the chloroplast genome (Newman et al., 1992). A different mutation in $p s b A$ also provides the cells with herbicide resistance to metribuzin (Przibilla et al., 1991).

The herbicide sulfometuron methyl (SMM) that inhibits growth of bacteria, yeast, algae and plants is commonly used as a selection marker in plants and algae. The target of SMM is the gene encoding acetohydroxyacid synthase (AHAS), an enzyme involved in the biosynthesis of branched amino acids. Since AHAS is encoded by the chloroplast genome of the red microalgae Porphyridium sp., it was found to be an ideal marker for chloroplast transformation. As such, a naturally occurring W492S mutation in the algal AHAS gene that confers resistance to SMM was used to establish a transformation system for Porphyridium sp. (Lapidot et al., 1999, 2002). During evolution, the gene encoding AHAS moved to the nucleus in land plants and green algae (Mazur et al., 1987), therefore allowing for its use as a selection marker in nuclear transformations in plants ( $\mathrm{Li}$ et al., 1992; Ott et al., 1996) and green algae (Kovar et al., 2002). The AHAS-encoding gene was also later used as a transformation marker for the green microalgae Lobosphaera (Parietochloris) incisa, an algae with added value for biotechnological purposes (Grundman et al., 2012). In this case, the endogenous gene was first cloned, the W605S mutation in the active site of the enzyme that confers resistance to SMM was introduced, and the mutated gene was used for nuclear transformation.

Another chloroplast transformation system based on resistance to herbicides was developed for Platymonas subcordiformis using the bacterial bar gene encoding phosphinothricin acetyltransferase, which confers tolerance to glufosinate, or its ammonium salt, DL-phosphinothricin. This latter compound is the active ingredient in several herbicides, including the widely used Basta. The bar gene was also described as a selection marker in tobacco (Lutz et al., 2001). The use of this system in algae resulted in the development of a useful tool and a suitable selection system for this algae that is not sensitive to most commonly used antibiotics, such as spectinomycin, streptomycin or kanamycin (Cui et al., 2014).

Finally, as will be discussed below (see Section Biotechnological Exploitation of Microalgae), antibiotic and herbicide markers may raise biosafety concerns when genetic engineering is recruited for biotechnological purposes. Thus, selections involving metabolic markers that offer functional complementation of a missing endogenous gene product provide a clear advantage.

\section{Regulatory Elements: Promoters, UTRs, and Codon Optimization}

Efficient expression of foreign genes in algal chloroplasts is usually best obtained through the use of endogenous regulatory elements, derived from genes that are abundantly expressed. Thus, promoters that drive expression of the large subunit of ribulose bisphosphate carboxylase/oxygenase $(r b c L)$, the D1 protein of the photosystem II reaction center ( $p s b A)$, and the $\mathrm{Y}$ subunit of ATP synthase (atpA), were recruited for this purpose. The highest expression of soluble GUS was recorded for the atp $A$ promoter and the $5^{\prime}$ UTR (Ishikura et al., 1999). In another study, the atp $A$ and $p s b D$ promoters and $5^{\prime}$ UTRs were shown to drive the highest expression of a GFP reporter gene, when compared to the promoter and $5^{\prime} \mathrm{UTR}$ s of the $r b c L$ and $p s b A$ genes. The presence of a $3^{\prime}$ UTR derived from the different genes was required but had little effect on the accumulation of the transcript and foreign protein (Barnes et al., 2005). In later studies, the Goldschmidt-Clermont group demonstrated that the use of the psaA-exon1, its promoter and its $5^{\prime}$ UTR increased foreign protein expression levels in the chloroplast. The authors also suggested that the variable expression observed among the different transformants that were derived from the same construct was related to the number and location of the recombination events (Michelet et al., 2011).

For a long time, foreign gene expression in the chloroplast suffered from low yields. With this in mind, limiting factors that could explain the low expression were extensively sought. It should be noted that gene expression in the chloroplast is tightly regulated at the translational level, and is less sensitive to transcriptional regulation. This was demonstrated in studies that inhibited the accumulation of specific chloroplast transcripts (by $90 \%)$ without affecting their translation rates. Gene dosage also proved to have little effect on the level of proteins encoded by these genes (Eberhard et al., 2002). The bottleneck in transgene expression from the chloroplast genome was addressed by the Mayfield group in 2007. They demonstrated that instead of targeting the expression cassette to the inverted repeats of the chloroplast genome, which yielded a low expression level of $0.5 \%$ 
relative to the total protein content in the cell, direct replacement of the $p s b A$ gene with a foreign coding region increased the production yield of the foreign protein to $>5 \%$. The authors suggested that the increased level of expression was due to a lack of competition encountered by regulatory factors (Mayfield and Schultz, 2004; Manuell et al., 2007).

Further improvements increased the level of transgene expression in the chloroplast of $C$. reinhardtii up to $20 \%$ of the total soluble protein content by focusing on optimization of codon usage and inhibition of ATP-dependent proteases. In addition, the toxicity of the transgene product may have a dramatic effect on its level of expression, and finally, large screens are usually required in order to isolate clones that efficiently express a transgene, possibly due to transformation-associated genotypic modifications that occur due to the random insertion of the foreign gene into the nuclear genome. Thus, the type of promoter and UTRs used are not the only factors that affect expression levels. The site of integration in the chloroplast, as well as accompanying random integration events in the nucleus, may also affect expression (Surzycki et al., 2009).

Chloroplast transformation systems that were developed for other algal species revealed differences with those developed for Chlamydomonas. For example, chloroplast transformation of Euglena revealed that the cassette containing the aadA gene flanked by the endogenous $p s b A$ promoter $/ 5^{\prime} \mathrm{UTR}$ and $3^{\prime}$ UTR generated drug resistant clones in which the DNA was maintained on a high molecular weight episomal element. Additional experiments using the aadA cassette introduced into the independently expressed Euglena gracilis $p s b K$ operon demonstrated proper splicing of the group III intron derived from the operon (Doetsch et al., 2001). Episomal elements carrying resistance genes are also common in nonphotosynthetic kinetoplastids, such as Leishmania (Kapler et al., 1990), although the algal case describes a stable chloroplast episome.

\section{Inducible Expression in the Chloroplast}

Inducible expression offers considerable advantages, especially when the product of the transgene may interfere with cell growth or be toxic. NAC2 is essential for stabilization of the $p s b D$ mRNA (Kuchka et al., 1989), binding a unique target site in the $p s b D$ $5^{\prime} \mathrm{UTR}$, and regulating the expression of any foreign gene under control of the $p s b D 5^{\prime} \mathrm{UTR}$. The group of Rochaix introduced the NAC2 gene into Chlamydomonas cells under control of the cytochrome $\mathrm{C}_{6}$ promoter, which can be induced upon depletion of copper ions, by exposure to anaerobic conditions and in the presence of nickel ions (Merchant and Bogorad, 1987; Nickelsen et al., 1994; Quinn et al., 2002, 2003; Surzycki et al., 2007; Rochaix et al., 2014). Thus, manipulating the NAC2 gene to be induced by any of these conditions resulted in a similar pattern of regulation of a foreign gene that was driven by the $p s b D 5^{\prime} \mathrm{UTR}$ (Rochaix et al., 2014).

\section{NUCLEAR TRANSFORMATION}

Nuclear expression of transgenes in microalgae offers several advantages, including targeting of foreign proteins for expression in organelles, such as the chloroplast, and protein glycosylation and/or additional post-translational modifications, as well as secretion (León-Bañares et al., 2004). These advantages are especially required for the exploitation of microalgae for industrial production for recombinant proteins, especially in view of the known difficulties to obtain efficient expression of foreign genes in microalgae (Eichler-Stahlberg et al., 2009). A collection of protocols for nuclear transformation, combined with the availability of several constitutive or inducible promoters and the availability of multiple selectable markers, offers a multitude of approaches for expression of transgenes in the nucleus.

\section{Gene Delivery Methods \\ Generation of Protoplasts}

The algal cell wall represents a physical barrier preventing the entry of foreign DNA through the cell membrane. Thus, many protocols for transformation rely on the use of protoplasts, which are cell wall-deficient. However, in many cases, generating protoplasts is a major bottleneck due to the diverse composition of the cell wall in different algae species, which, in many cases, remain poorly characterized (Popper and Tuohy, 2010). The Chlamydomonas cell wall is built from glycoproteins and contains little cellulose or chitin. As such, polysaccharidedegrading enzymes are ineffective, with protoplasts instead being generated by incubation with autolysins, namely hydroxylproline-specific proteases that are active during gametogenesis and mating (Jaenicke et al., 1987; Imam and Snell, 1988). Unlike Chlamydomonas, the cell wall in Chlorella consists of sugar polymers that can be degraded by sugar digesting-enzymes (Takeda, 1991). Thus, protoplasts of different Chlorella species can be generated by incubation with different sugar-degrading enzyme mixes (Braun and Aach, 1975; Yamada and Sakaguchi, 1982; Afi et al., 1996). Protoplasts from red and brown algae have been prepared using numerous cell wall-digesting enzymes extracted from marine mollusks or echinoderms (Liu et al., 1984; Cheney et al., 1986; Reddy et al., 2010).

\section{Biolistic Delivery}

The most frequently used method of gene delivery is biolistic transformation, also referred to as micro-projectile bombardment. This method utilizes DNA-coated gold or tungsten micro-particles that are delivered through a particle delivery system at high velocity into algal cells, surpassing the physiological barrier of the cell wall. Successful transformation by this approach have been reported for C. reinhardtii (Kindle et al., 1989), Dunaliella salina (Tan et al., 2005), Haematoccucs pluvialis (Steinbrenner and Sandmann, 2006), and diatoms (Dunahay et al., 1995; Apt et al., 1996; Falciatore et al., 1999; Zaslavskaia et al., 2000).

\section{Glass Beads Method}

A simple method that is often used for gene delivery is based on agitating protoplasts or cell wall-deficient mutants in the presence of glass beads, polyethylene glycol (PEG) and foreign DNA (Kindle et al., 1989). Successful transformations by this method were reported for C. reinhardtii (Kindle et al., 1989) 
and Chlorella ellipsoidea (Jarvis and Brown, 1991). In the case of $C$. reinhardtii, linearized plasmids usually yield higher transformation frequencies than supercoiled DNA when using glass beads or silicon carbide whiskers to mediate DNA entry (Kindle, 1990; Dunahay, 1993).

\section{Electroporation}

Applying an electric pulse is a commonly used method to introduce DNA into cells. This technique was used to transform microalgal protoplasts, cell wall-deficient mutants, and other thin walled algal cells. It was used to transform C. reinhardtii (Brown et al., 1991; Shimogawara et al., 1998; Yamano et al., 2013), D. salina (Walker et al., 2005b), Chlorella vulgaris (Chow and Tung, 1999), Scenedesmus obliquus (Guo et al., 2013), and Nannochloropsis sp. (Kilian et al., 2011). The use of cell wall-deficient strains improves transformation efficiency, with successful transformation using this methodology having been reported for Lobosphaera (Zorin et al., 2014). However, successful transformation without using cell wall mutants was also shown in P. tricornutum, either by electroporation (Niu et al., 2012; Zhang and $\mathrm{Hu}, 2014$ ) or multi-pulse electroporation (Miyahara et al., 2013). In all these cases, the cells were grown without silica, which probably influenced cell wall structure. Overall, reducing cell wall thickness improves the transformation of microalga by electroporation.

\section{Agrobacterium-Based Transformation of Microalgae}

The highly popular system for nuclear transformation of land plants using Agrobacterium tumefaciens was also adapted for transformation of microalga, using the pCAMBIA transformation vector. Several microalgal species were transformed by Agrobacterium, including Chlamydomonas (Kumar et al., 2004; Pratheesh et al., 2014), as well as other algae of biotechnological value, such as $H$. pluvialis (Kathiresan et al., 2015), Schizochytrium (Cheng et al., 2012), Isochrysis galbana, and Isochrysis sp. (Prasad et al., 2014).

\section{Nuclear Promoters and Control Elements Gene Promoters}

Efficient expression of foreign genes is achieved under the control of strong promoters. These are often derived from viruses, especially in land plants (Sanger et al., 1990), or from highly abundant endogenous genes, such as the small subunit of Rubisco (Goldschmidt-Clermont and Rahire, 1986). The use of a Cauliflower Mosaic Virus (CaMV35S) heterologous promoter that functions well in land plants gave inconsistent results when used to transform different algae species. Whereas, this promoter could drive the expression of reporter genes or chimeric genes in D. salina (Tan et al., 2005), Chlorella kessleri (El-Sheekh, 1999), and the dinoflagellates Amphidinium sp. and Symbiodinium microadriaticum (ten Lohuis and Miller, 1998; see Table 2) it gave contradictory results in C. ellipsoidea (Jarvis and Brown, 1991; Kim et al., 2002) and C. reinhardtii (Day et al., 1990; Blankenship and Kindle, 1992; Kumar et al., 2004; Diaz-Santos et al., 2013).

The use of strong endogenous promoters is recommended for nuclear transformation in algae, since heterologous promoters did not have an advantage, although they were active (DiazSantos et al., 2013). Among the endogenous regulatory elements, the $R B C S 2$ promoter that drives expression of the small subunit of Rubisco, and PSAD (an abundant chloroplast protein of the Photosystem I complex) from C. reinhardtii drove efficient expression of transgenes (Stevens et al., 1996; Lumbreras et al., 1998; Fuhrmann et al., 1999; Fischer and Rochaix, 2001). Improved expression of transgenes was demonstrated in $C$. reinhardtii when the $R B C S 2$ promoter was fused with the HSP70A (heat shock protein 70A) promoter, which acts as a transcriptional enhancer when placed upstream of the RBCS2 promoter (Schroda et al., 2000). Driving expression by the HSP70A/RBCS2 regulatory elements has become highly recommended for nuclear transformation of Chlamydomonas.

Other endogenous promoters have been used to drive the expression in other algal species, such as the promoter of the fucoxanthin-chlorophyll binding protein (FCP; Falciatore et al., 1999; Zaslavskaia et al., 2000; Poulsen et al., 2006). In the unicellular green alga Lobosphaera (Parietochloris) incisa, the endogenous $R B C S$ promoter was used to drive expression of the ble gene, thus developing a platform for future successful engineering of this alga, which has great biotechnological potential due to its long-chain polyunsaturated fatty acid (PUFA) metabolism (Zorin et al., 2014).

Elements in the promoter region may occasionally have a negative effect on the expression of a transgene. Expression of the ble gene was silenced in $80 \%$ of transformants when it was driven from the $R B C S$ promoter alone. However, when it was introduced under the control of the $H S P 70 A / R B C S$ tandem promoter, silencing occurred in only $36 \%$ of transformed cells (Schroda et al., 2002). Modifying the HSP70A/RBCS2 promoter so that it contained four copies of the first RBCS2 gene intron between the HSP70A and RBCS2 promoters significantly increased the expression of the downstream gene (Rasala et al., 2012).

A recent study described the use of the constitutive endogenous promoter that drives expression of the Glyceraldehyde-3-Phosphate Dehydrogenase (GAPDH), for expression of the bacterial gene encoding bialaphos resistance (bar) and of the $N$-terminal fragment of human canstatin in $D$. salina (Jia et al., 2012).

A search for efficient endogenous promoters was performed by a "promoter trapping approach" in C. reinhardtii, by which a promoter-less selectable marker gene was randomly integrated into the nuclear genome (von der Heyde et al., 2015). The appearance of drug-resistant colonies indicated that the selectable marker gene integrated near a strong promoter. This approach, combined with the growing amount of species whose genomes have been sequenced, should enable the isolation of strong endogenous promoters in other algae as well.

\section{Inclusion of Splicing Signals}

Another point of concern is the inclusion of signals for RNA processing in the algal nuclei, since only processed mRNAs can exit the nucleus through the nucleopores. Thus, expression cassettes that contain an endogenous intron were prepared for improvement of transgene expression (Lumbreras et al., 1998; Fischer and Rochaix, 2001; Kovar et al., 2002). 


\section{Optimization of Codon Usage}

The absence of tRNAs that are compatible with the codon usage of a given gene can dramatically affect expression of a transgene (Heitzer et al., 2007). Differences in codon usage were recorded between various microalgal species, as well as for the chloroplast and nuclear genomes of the same species (León-Bañares et al., 2004) and between organelles (Jarvis et al., 1992). Therefore, codon optimization of exogenous genes can significantly improve protein expression (Zaslavskaia et al., 2000; Franklin et al., 2002).

\section{Inducible Expression in the Nucleus}

The biotechnological exploitation of constitutive promoters for the effective expression of toxic compounds for industrial or pharmaceutical uses or for establishing silencing systems may occasionally be problematic. Hence, introducing inducible expression systems offers considerable advantages. Overall, the use of inducible systems is also attractive for large-scale production of recombinant proteins in microalgae, as these enable the cells to first reach an optimal concentration before expression of the transgene is initiated.

Nitrogen metabolism is based on the exploitation of ammonium ions. However, some algae can adsorb nitrate and convert it into ammonium with the help of nitrate reductase (Fernandez et al., 1989; Berges, 1997). The promoter of the nitrate reductase gene that is switched on and off in response to the presence of nitrate or ammonium ions (Poulsen and Kroger, 2005) was able to promote the inducible expression of a reporter gene in Cylindrotheca fusiformis (Poulsen and Kroger, 2005), C. reinhardtii (Schmollinger et al., 2010), C. ellipsoidea (Wang et al., 2004), D. salina (Li et al., 2007, 2008), Volvox carteri (von der Heyde et al., 2015), and Phaeodactylum triornutum (Niu et al., 2012).

The use of light for inducing expression in microalgae has long been pursued, initially by the use of the CABII-1 promoter that was shown to respond to changing light conditions and stimulate expression of the NIT1 gene under light in Chlamydomonas (Blankenship and Kindle, 1992). More recently, the light-regulated elements of the light-inducible protein (LIP) from Dunaliella was mapped to the flanking 400 bp upstream sequences of the LIP gene, which contains triplicates of lightresponsible motifs. These were shown to induce expression of a heterologous reporter gene in Chlamydomonas (Park et al., 2013; Baek et al., 2016).

The metal-responsive CYC6 promoter that is repressed by copper was used for inducible gene expression in C. reinhardtii (Quinn and Merchant, 1995). The copper response element $(C U R E)$ is responsive to both nickel and cobalt ions, and could be inhibited by EDTA (Quinn et al., 2003). Expression from this inducible system was improved by the addition of the first intron of the RBCS2 gene to the CYC6 promoter (Ferrante et al., 2011). In several marine and freshwater algae species, a control element located upstream of the $\mathrm{B}_{12}$ independent methionine synthase (METE) gene could repress the expression of a reporter gene following addition of $\mathrm{B}_{12}$ (Helliwell et al., 2014). The strong repressible nature and high sensitivity of the $\mathrm{B}_{12}$-responsive element can, therefore, be used as another promising gene expression tool for biotechnological applications.

Yet another element that was used to drive transgene expression is based on riboswitch biology (Mandal and Breaker, 2004). A riboswitch-regulated element based on the thiamine pyrophosphate (TPP) biosynthesis was identified in the THIC genes of a variety of organisms (Breaker, 2012), including Arabidopsis, where it affected THIC mRNA stability by alternative splicing of the primary mRNA (Bocobza et al., 2007; Wachter et al., 2007; Bocobza and Aharoni, 2014). This TPP riboswitch was later used for generating an inducible expression system in Arabidopsis (Bocobza et al., 2013) and in C. reinhardtii (Ramundo et al., 2013). Using the TPP system, Ramundo and colleagues were able to conditionally repress expression of the rpoA or rps12 genes in the chloroplast, affecting their organelle transcription or translation, respectively. Although riboswitch elements are common in prokaryotes, and have been used to generate inducible expression systems in bacteria (Neupert and Bock, 2009), the only riboswitch to be identified in higher eukaryotes was the TPP riboswitch, described above. The use of riboswitchbased regulation was recently used to develop a system for increasing expression of chloroplast genes in Arabidopsis, via an RNA amplification-based system that strongly improves the efficiency of riboswitches (Emadpour et al., 2015). A summary of the constitutive and inducible expression systems is given in Table 2.

\section{Nuclear Selectable Marker Genes}

Stable transformation is based on the use of a proper selection marker. These include genes that confer resistance to antibiotics or herbicides, and various metabolic enzymes that control growth under specific nutritional conditions. A collection of nuclear selective genes are listed in Table 3.

\section{Selection of Nuclear Transformants Based on Auxotrophic Growth}

Auxotroph genes can be used as selection markers for rescuing the phenotype of specific mutants that restrict growth under minimal conditions. The NIT1 gene, encoding nitrate reductase, promotes growth in the presence of nitrates as a nitrogen source (Fernandez et al., 1989), and was introduced for the nuclear transformation of the NIT1 mutant of $C$. reinhardtii (Kindle et al., 1989). This useful selection system was also applied for many other algal species (see Table 3). Another metabolic marker is the $A R G 7$ gene, encoding argininosuccinate lyase. It was used to rescue arginine-requiring $A R G 7$ mutants to prototrophy (Debuchy et al., 1989; Haring and Beck, 1997), and is commonly used for nuclear transformation of $C$. reinhardtii. The ARG7 mutant strain has been widely used for transformation of Chlamydomonas, mostly for basic research. A similar approach for use with other algae would be welcome, although a mutant that does not express argininosuccinate lyase must first be isolated. Another selection marker is based on NIC7, encoding quinolinate synthetase that is required for NAD biosynthesis. A plasmid carrying this gene could rescue a mutation in the $C$. reinhardtii NIC1 gene (Ferris, 
TABLE 3 | List of selection markers and selection modes for nuclear transformation.

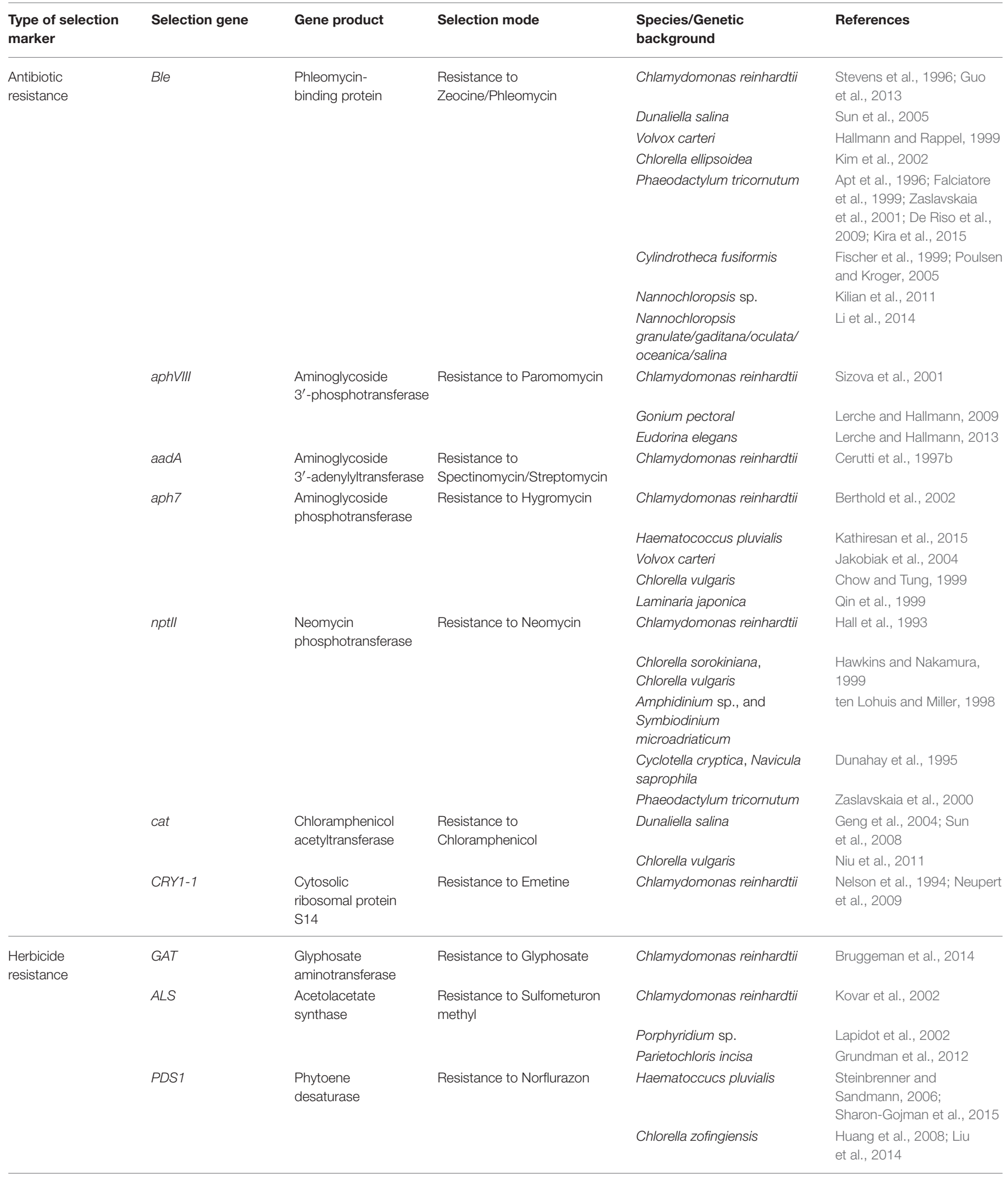


TABLE 3 | Continued

\begin{tabular}{|c|c|c|c|c|c|}
\hline $\begin{array}{l}\text { Type of selection } \\
\text { marker }\end{array}$ & Selection gene & Gene product & Selection mode & $\begin{array}{l}\text { Species/Genetic } \\
\text { background }\end{array}$ & References \\
\hline \multirow[t]{8}{*}{ Metabolic markers } & NIT1 & Nitrate reductase & $\begin{array}{l}\text { Growth in the presence of } \\
\text { nitrate salt }\end{array}$ & $\begin{array}{l}\text { Chlamydomonas reinhardtii } \\
\text { (nit1-) }\end{array}$ & Kindle et al., 1989 \\
\hline & & & & Volvox carteri (nit1-) & $\begin{array}{l}\text { Schiedlmeier et al., 1994; } \\
\text { Hallmann and Sumper, } \\
1996\end{array}$ \\
\hline & & & & Dunaliella viridis (nit1-) & Sun et al., 2006 \\
\hline & & & & Chlorella sorokiniana (nit1-) & Dawson et al., 1997 \\
\hline & & & & Chlorella ellipsoidea (nit1-) & Bai et al., 2013 \\
\hline & ARG7 & $\begin{array}{l}\text { Argininosuccinate } \\
\text { lyase }\end{array}$ & $\begin{array}{l}\text { Growth in Arginine free } \\
\text { media }\end{array}$ & $\begin{array}{l}\text { Chlamydomonas reinhardtii } \\
\text { (arg7-) }\end{array}$ & $\begin{array}{l}\text { Debuchy et al., 1989; } \\
\text { Haring and Beck, 1997; } \\
\text { Molnar et al., } 2009\end{array}$ \\
\hline & NIC7 & $\begin{array}{l}\text { Quinolinate } \\
\text { synthetase }\end{array}$ & $\begin{array}{l}\text { Growth in Nicotinamide free } \\
\text { media }\end{array}$ & $\begin{array}{l}\text { Chlamydomonas reinhardtii } \\
\text { (nic7-) }\end{array}$ & $\begin{array}{l}\text { Ferris, 1995; Adam et al., } \\
\text { 2006; Lin et al., } 2010\end{array}$ \\
\hline & OEE1 & $\begin{array}{l}\text { Oxygen-evolving } \\
\text { enhancer protein1 }\end{array}$ & Photoautotrophic growth & $\begin{array}{l}\text { Chlamydomonas reinhardtii } \\
\text { (oee1-) }\end{array}$ & Mayfield and Kindle, 1990 \\
\hline
\end{tabular}

1995; Lin et al., 2010), allowing growth in the absence of nicotinamide.

\section{Selection of Nuclear Transformants Based on Resistance to Antibiotics}

As with animal cell systems, numerous antibiotics genes have been successfully used as selection markers of microalgae. The ble gene that was originally isolated from Streptoalloteichus hindustanus, confers resistance to zeomycin and phleomycin (Sugiyama et al., 1994) and was used for generating transgenic clones of different algal species (see Table 3). The synthetic aminoglycoside adenyltransferase aadA gene confers resistance to spectinomycin and streptomycin (Svab and Maliga, 1993). It was originally used for chloroplast transformations but was further adopted for the nuclear system in Chlamydomonas (Cerutti et al., 1997b), and H. pluvialis (Gutiérrez et al., 2012). The aminoglycoside phosphotransferase genes aphVIII $(a p h H)$ from Streptomycesrimosus and aph7 from Streptomyces hygroscopicus confer resistance to paromomycin (Sizova et al., 2001) and hygromycin B, respectively. These were used to select drug-resistant algae in several species (see Table 3). The bacterial nptII gene encoding neomycin phosphotransferase was proven to be relatively inefficient in C. reinhardtii (Bingham et al., 1989; Hall et al., 1993). Codon optimization of the nptII gene, however, led to its improved function as a nuclear selection marker (Barahimipour et al., 2016). This selection marker was more successful when used for transforming other algal strains (see Table 3), as well as seed plants (Elghabi et al., 2011). The use of the cat gene, encoding CAT that confers resistance to chloramphenicol, has also been widely used (Table 3). Finally, the mutated version of the $C$. reinhardtii gene encoding ribosomal protein $S 14$ (CRY1) confers resistance to emetine and cryptopleurine, and was adopted as a dominant selection marker (Nelson et al., 1994). Indeed, most antibiotic resistance genes have been successfully and routinely used for algal transformations (see Table 3). Nonetheless, their use as selection markers raises both health and ecological concerns for large-scale production in plants and microalgae.

\section{Selection of Nuclear Transgenic Algae Based on Herbicide Resistance}

The demand for production of plants and microalgae that are free of antibiotic resistance markers encouraged the use of herbicide-resistance markers, such as acetohydroxyacid synthase (ALS/AHAS) that confers resistance to sulfometuron methyl (SMM), phytoene desaturase (PDS) that generates resistance to the bleaching herbicide norflurazon, and glyphosate acetyltransferase $(G A T)$ that contributes to resistance against glyphosate (Malik et al., 1989).

ALS/AHAS catalyzes the first step in the biosynthesis of the branched-chain amino acids, valine, leucine, and isoleucine (Kishore and Shah, 1988; Chipman et al., 1998). It is the target enzyme of the SMM herbicide that effectively inhibits growth of bacteria, yeast, plants, and algae. A mutant form of the gene encoding ALS/AHAS was used as a dominant selectable marker in the green algae Lobosphaera (Parietochloris) incisa (Grundman et al., 2012), based on experience gained from transformation of the chloroplast of the unicellular red alga Porphyridium sp. (Lapidot et al., 2002), and the green algae C. reinhardtii (Kovar et al., 2002).

PDS functions in the carotenoid biosynthesis pathway. Inhibition of this enzyme causes degradation of chlorophyll and the chloroplast membrane, as well as photo-bleaching of green tissues (Boger and Sandmann, 1998). Point mutations in $P D S$ confer enhanced resistance to the bleaching herbicide norfurazon in the green microalgae $H$. pluvialis (Steinbrenner and Sandmann, 2006; Sharon-Gojman et al., 2015) and Chlorella zofingiensis (Huang et al., 2008; Liu et al., 2014). The use of GAT that confers increased tolerance to glyphosate is less recommended due to the reduced growth of GAT-expressing transformants in response to high concentrations of glyphosate, which were required to inhibit wild type cells (Bruggeman et al., 2014). 


\section{Targeting of Foreign Proteins to the Chloroplast}

Targeting foreign proteins to sub-cellular compartments can affect their expression yield through protein folding, assembly and post-translational modifications. For example, the chloroplast provides an oxidizing environment that promotes the formation of disulfide bridges, and an abundance of chaperones that are required for the folding of soluble proteins after their import. The ability to properly fold and generate native disulfide bridges is fundamental for generating functional proteins and protein complexes, thus making the chloroplast an attractive organelle for the expression of recombinant proteins. This was demonstrated in $C$. reinhardtii by the production of the disulfide-containing Pfs 25 protein from Plasmodium falciparum, which blocks transmission of the malaria parasite (Gregory et al., 2012). The importance of disulfide bond formation was also demonstrated by monitoring the expression and assembly of several fully active antibodies against pathogenic agents (Mayfield et al., 2003; Mayfield and Franklin, 2005).

Another advantage of organelle-specific expression is that targeting of nuclear-expressed proteins to chloroplasts can reduce the danger of proteolysis (Barnes et al., 2005; Doran, 2006; Mayfield et al., 2007). However, it still remains unclear why the ability to accumulate high levels of exogenous proteins in the chloroplast is heterogeneous. The plastid contains three large families of proteases, each of bacterial origin. These include the ATP-dependent Zn-metallo protease FtsH family (Adam et al., 2006; Liu et al., 2010), the ATP-independent Deg/HtrA family of serine endopeptidases (Huesgen et al., 2009; Sun et al., 2010) and the ATP-dependent serine-type Clp family (Adam et al., 2006). The chloroplast proteases can cleave exogenous proteins, as demonstrated in $C$. reinhardtii by the use of cyanide m-chlorophenylhydrazone (CCCP), which uncouples chloroplast and mitochondrial energy production. The presence of CCCP reduced degradation of the model protein VP28 from the White Spot Syndrome Virus three-fold expressed in the chloroplast, demonstrating that ATP-dependent proteases are involved in degrading this protein (Surzycki et al., 2009). Most chloroplast proteases are encoded in the nucleus, except for ClpP1. Thus, attempts to limit proteolysis of foreign genes expressed in the chloroplast can be controlled by knockdown technologies, such as RNAi, an approach that still requires further improvement in microalgae. Attempts to reduce expression of chloroplast-encoded ClpP by riboswitch control resulted in malfunctioning cells (Ramundo et al., 2014). However, deletion of the gene encoding ClpP protease from the chloroplast was achieved in A. thaliana (Zheng et al., 2006; Stanne et al., 2009), indicating that this approach could be feasible for microalgae as well.

Protein toxicity should also be considered when expression of foreign proteins in photosynthetic organisms is attempted. For example, the toxic effect of avidin, when expressed in the cytosol of transgenic tobacco plants, can be surpassed when this molecule is targeted to the vacuole (Murray et al., 2002). This also holds true for the cholera toxin-B subunit that is toxic to tobacco cells when expressed in the cytosol but not in the chloroplast (Daniell et al., 2001). Similar aspects should be considered when expressing foreign genes in microalgae.
Attempts to identify a consensus sequence shared by chloroplast and mitochondrial targeting peptides (cTPs and mTPs, respectively) were only partially successful (Habib et al., 2007; Huang et al., 2009). For this reason, data-driven machine learning techniques were developed (Schneider and Fechner, 2004), leading to the development of several programs, such as TargetP and Predotar (Emanuelsson et al., 2000; Emanuelsson, 2002; Small et al., 2004), that try to predict targeting peptides (TPs) for land plants. ChloroP is another program that predicts cleavage sites of TPs (Emanuelsson et al., 1999). These programs are based on the detection of an $\mathrm{N}$-terminal targeting sequence that is shared between different targeted polypeptides. However, since green algae diverged from land plants over 725-1200 million years ago (Becker and Marin, 2009), their organelle import machineries, as well as their TPs, differ substantially from those of land plants. As such, most prediction programs are less reliable when used to predict the localization of algal proteins (Patron and Waller, 2007). With this in mind, a new algorithm, PredAlgo, that identifies cTPs/mTPs in green algae was developed. It is based on the accumulation of a large dataset from large- and small-scale proteomic studies of Chlamydomonas organelles (https://giavap-genomes.ibpc.fr/cgibin/predalgodb.perl?page=main; Tardif et al., 2012).

A recent study, based on the genomes of $P$. tricornutum and Thalassiosira pseudonana, provides a detailed analysis of TP motifs that target nuclear-encoded proteins to chloroplasts in diatoms and algae with secondary plastids of the red lineage (i.e., dinoflagellates, cryptophytes, and stramenopiles; Gruber et al., 2015). Organisms that belong to these phyla are of great interest to algae-based industry.

\section{Targeting Transgene Products for Expression in Specific Organelles or Secretion}

Targeting a transgene protein product for secretion is a common strategy for avoiding its degradation. A dedicated vector was designed in which luciferase expression in C. reinhardtii was greatly improved (up to $84 \%$ ) by fusing the transgene with the previously identified secretion element of carbonic anhydrase (Lauersen et al., 2013a). This approach was further implemented for the production of secreted ice-binding protein, a protein of considerable industrial value (Lauersen et al., 2013b, 2015).

The targeting of nuclear transformation proteins to different cellular compartments is achieved by the addition of a TPencoding sequence at the $5^{\prime}$-end of the transgene. TPs are recognized by the import machineries, which direct import into the proper organelle. Vectors that efficiently and specifically target transgene products to different compartments were generated (Rasala et al., 2014). Such vectors introduce TPs to the nucleus, mitochondria, chloroplast and ER using the nuclear localization signal (NLS) from simian virus 40 , the $\mathrm{N}$-terminal mTP from the nuclear gene encoding the alpha subunit of the mitochondrial ATP synthase, the N-terminal cTP from the photosystem I reaction center subunit II (encoded by psaD), and the ER-transit sequence from either BiP1 or ARS1, respectively. The TP that targets proteins to peroxisomes was also identified and was further shown to target a GFP transgene to the peroxisome of C. reinhardtii (Hayashi and Shinozaki, 2012). 
In some cases, protein tagging is required for downstream applications, such as pull-down assays, immunoprecipitation, or protein purification. The introduction of such tags could interfere with the targeting signals. To prevent the obscuring of subcellular targeting signals, it is important to identify the TP of the native protein. In Chlamydomonas, endogenous proteins are usually tagged at their C-termini, since TPs are most frequently found at the N-terminus (Franzen et al., 1990; Patron and Waller, 2007).

\section{Increasing the Efficiency of Transgene Nuclear Expression}

While chloroplast transformation toolkits have been established for several microalgae, similar tools for nuclear-based protein expression remain under-developed, as for land plants. The reasons that lead to the low expression of transgenes from the nuclear genome could be varied, including the effects of position on integration events, epigenetic-derived transgene silencing, and difficulties related to variable codon usage systems (Jinkerson and Jonikas, 2015). Although the precise mechanism of insertion of DNA into the genome is unknown, it involves ligation of the transforming DNA at a site of double-stranded genomic DNA break, an event that occurs randomly throughout the genome with little sequence specificity, via the non-homologous end joining repair pathway (Kindle et al., 1989; Mayfield and Kindle, 1990; Zhang et al., 2014). In some cases, the transformed DNA integrates as a whole cassette, although truncated versions, fragments, or multiple cassettes that result from enzymatic cleavage can also be inserted (Zhang et al., 2014). Random integration events can sometimes result in "position effects," in which the level of transgene expression is influenced by the surrounding genomic regions (Leon and Fernandez, 2007). It is generally accepted that screening of a large number of transformants in search of a high expressing clone is necessary (Hallmann, 2007).

\section{Generation of Strains for Improved Transgene Expression}

Despite the great advances made in developing systems for algal transformation, with $C$. reinhardtii serving as a fully sequenced model organism (Blaby et al., 2014), transgene expression using different methodologies and approaches remained limited until specific mutant strains capable of increased expression were isolated (Neupert et al., 2009). The basic assumption was that transgene expression could be affected by epigenetic processes, although the exact reasons remained unclear. To overcome this, a genetic screen was established in which wild type $C$. reinhardtii cells were subjected to random mutagenesis, and further screened for colonies that showed increased expression of the transgene. The screen used the $\mathrm{ARG}^{-}$selection system to select for transgenic algae, although another level of selection was introduced to screen for clones with increased expression. This was achieved by introducing CRY1-1, a ribosomal gene that confers resistance to emetine in a dose-responsive manner. As such, clones with increased CRY1-1 expression could grow in the presence of high emetine concentrations. Two clones, UVM4 and UVM11, were selected for increased transgene expression and are currently used for in Chlamydomonas (Lauersen et al., 2013b).
It is tempting to examine whether a parallel system could be developed for other algae as well.

\section{Improvement of Transgene Expression by Fusion with a Selection Marker}

An expression cassette in which the codon-optimized GFP gene was fused to the ble selection marker increased GFP expression in C. reinhardtii (Fuhrmann et al., 1999). A further improvement was achieved by including the self-cleavable $2 \mathrm{~A}$ peptide derived from the foot and mouth disease virus (Ryan et al., 1991) between the transgene and the ble selection marker. Its presence resulted in processing of the fused polypeptides to yield two independent proteins. This system led to an $\sim 100$-fold increase in the expression of several transgenes (Rasala et al., 2012, 2013).

The combination of using novel algal strains that promote increased expression of foreign genes, along with the sophisticated fusion between selection and target genes, opens a new era in transgene expression by the green algae Chlamydomonas, although similar developments with other algae are called for as well. The use of Chlamydomonas overexpressing strains (i.e., UVM11), combined with the codon optimization of the target gene, was shown to overcome the expression barrier of transgenes in Chlamydomonas. This approach led to the efficient expression of an HIV vaccine candidate, P24 (Barahimipour et al., 2016).

\section{Expression of Transgenes from Episomes}

A recent study reported the development of a nuclear episomal vector designed to introduce foreign DNA from E. coli into two diatom species, $P$. tricornutum and T. pseudonana, via conjugation. The vector contained a yeast-derived sequence that promoted its replication in these diatoms, even after antibiotic selection was eliminated. This episome was maintained as a closed circle at a copy number equivalent to the number of native chromosomes (Karas et al., 2015). This system offers great advantages in that it offers an easy method for introducing large DNA fragments into the host microalga, possibly promoting entry of several genes comprising a metabolic pathway. In addition, it is expected, although has yet to be shown, that expression of foreign genes from an episome would be less interrupted by epigenetic mechanisms or positional effects, since the DNA is not integrated into the chromosomal genome.

\section{Gene Targeting in Algal Nuclei}

Nuclear transformation of microalgae, in most studied cases, exhibited low frequency of homologous recombination (Sodeinde and Kindle, 1993; Nelson and Lefebvre, 1995), as was also observed with most photosynthetic organisms, except for mosses. Although occasional successful homologous recombination in the nuclei of Chlamydomonas had been reported in the past (Sodeinde and Kindle, 1993; Nelson and Lefebvre, 1995; Dawson et al., 1997; Hallmann et al., 1997; Minoda et al., 2004; Zorin et al., 2005), its frequency was too low for adaptation as a recommended technology. Efficient homologous recombination suitable for biotechnology applications was recorded in only two eukaryotic algae, 
namely Cyanidioschyzon merolae (Minoda et al., 2004) and Nannochloropsis sp. (Kilian et al., 2011).

Attempts to overcome difficulties that arise from positional effects and/or random integration of transgenes included the development of a $\mathrm{Zn}$-finger nuclease system (Townsend et al., 2009) that can recognize and cleave a relatively long specific sequence, generating site-specific double-strand DNA breaks, thus modifying a gene of interest, as shown for the COP3 gene encoding a light-activated ion channel (Sizova et al., 2013). Another methodology that is currently being developed for microalgae is based on the CRISPR/Cas9 system, which uses a guide RNA that directs the Cas9 nuclease to restrict a specific sequence of DNA (Jinek et al., 2012). Components of the CRISPR/Cas9 system have recently been shown to function in a transient manner in C. reinhardtii, although the high toxicity of Cas 9 prevented the successful recovery of stable colonies (Jiang et al., 2014). As such, further improvement of the CRISPR/Cas9 system is required.

Nuclear transgenic expression in microalgae is occasionally inefficient, possibly due to gene silencing (Cerutti et al., 1997a), or other reasons that are not yet fully understood. Still, even if all the elements required for optimal transcription and translation of transgene are provided, expression of exogenous genes can be very low or even non-existent, possibly due to gene silencing (Cerutti et al., 2011). Furthermore, expression of exogenous genes might be eliminated if transgenic algae clones are not maintained under constant selection conditions.

\section{Gene Silencing in Algae through the RNAi Machinery}

The recent sequencing of several algal genomes has provided insight into the great complexity of these species, although algal physiology and metabolomics are still not fully resolved. Nonetheless, key components of the RNA-mediated silencing machinery, such as Dicer and Argonaute that can process doublestranded RNA (dsRNA) into small interfering RNAs (siRNAs; Sontheimer and Carthew, 2005; Ghildiyal and Zamore, 2009; Voinnet, 2009; Fabian et al., 2010), have been found in many algae species, including C. reinhardtii (Schroda, 2006; Merchant et al., 2007; Kim and Cerutti, 2009), V. carteri (Ebnet et al., 1999; Cheng et al., 2006; Prochnik et al., 2010), D. salina (Sun et al., 2008; Jia et al., 2009), P. tricornutum (Bowler et al., 2008; De Riso et al., 2009), and E. gracilis (Iseki et al., 2002; Ishikawa et al., 2008). RNA-mediated silencing pathways have been studied in the unicellular green alga $C$. reinhardtii, where they are used as a reverse genetics tool for targeted knockdown of a variety of genes (Sineshchekov et al., 2002; Rohr et al., 2004; Soupene et al., 2004; Schroda, 2006). RNAi methodology was also used to examine the function of Aureochrome, a photoreceptor required for photomorphogenesis in stramenopiles. Silencing of the AUREO2 gene by introduction of dsRNA derived from the target gene induced the formation of sex organ primordia instead of branches, implicating it in the initiation of the development of a branch but not of a sex organ (Takahashi et al., 2007).
RNA-mediated silencing pathways have been studied in the unicellular green alga C. reinhardtii and used as a reverse genetics tool for targeted knockdown of a variety of genes (Sineshchekov et al., 2002; Rohr et al., 2004; Soupene et al., 2004; Schroda, 2006). The use of artificial miRNAs (amiRNAs), which mimic the structure of endogenous miRNA precursors was designed to enhance this approach (Molnar et al., 2009; Zhao et al., 2009). AmiRNAs can be designed by the microRNA designer platform (WMD3, http://wmd3.weigelworld.org/cgi-bin/webapp.cgi, active on March 14, 2016), which identifies suitable amiRNA candidates, based on optimal and specific hybridization properties, to target mRNA (Ossowski et al., 2008). Stable RNAi gene silencing was demonstrated in different microalgae as well, including V. carteri (Ebnet et al., 1999; Cheng et al., 2006), D. salina (Jia et al., 2009), P. tricornutum (De Riso et al., 2009), and E. gracilis (Iseki et al., 2002). Non-integrative dsRNA or siRNA was also used to trigger temporary RNAi in the green alga $D$. salina (Sun et al., 2008), E. gracilis (Ishikawa et al., 2008), and Vaucheria frigida (Takahashi et al., 2007).

\section{BIOTECHNOLOGICAL EXPLOITATION OF MICROALGAE}

Microalgae offer substantial potential for various biotechnological purposes, including production of animal food, aquaculture and marine agriculture, and biosynthesis of medical products, such as oral vaccines for animals (fish) and humans, high-value nutritional additives (e.g., polyunsaturated fatty acids, carotenoids, etc.), food dyes, and compounds used in the cosmetic industry and various other chemicals, in addition to possible future uses as a sources of energy. Moreover, microalgae-based technologies can be developed into water source treatments. These highly attractive goals justify the great efforts that the scientific community is investing in the development of molecular tools for the generation of transgenic microalgae.

\section{Using Synthetic Biology for the Production of Commercial Added Value in Algae}

In view of the difficulties in obtaining a high level of transgene expression in the cytoplasm of algae, the production of numerous therapeutic proteins was targeted to the chloroplast, including antibodies and proteins for use as oral vaccines. For example, a single-chain antibody was produced against the herpes simplex virus glycoprotein D (Mayfield et al., 2003; Mayfield and Franklin, 2005), and an IgG1 monoclonal antibody was generated against the anthrax protective antigen 83 (Tran et al., 2009). There were also attempts to use the chloroplast for producing oral vaccines against malaria (Gregory et al., 2012, 2013; Jones et al., 2013; Patra et al., 2015), Staphylococcus aureus (Dreesen et al., 2010), the white spot syndrome virus protein 28 (Surzycki et al., 2009), the P57 antigen bacterial kidney disease, (Siripornadulsil et al., 2007), and the VP1 antigen of foot and mouth disease virus fused to the Cholera toxin B subunit (Sun et al., 2003). Microalgae were exploited for the production of other immune reactive proteins, such as the human glutamic acid 
decarboxylase, a known auto-antigen in type 1 diabetes (Wang et al., 2008).

Heterologous therapeutic proteins were expressed not only in the chloroplast, but also in the nuclei of different algae, such as D. salina, Porphyridium sp., Nannocholorpsis oculata, and C. reinhardtii, to produce edible vaccines against the malaria parasite Plasmodium berghei (Dauvillée et al., 2010), the surface antigen of Hepatitis B virus (Geng et al., 2003) and for the production of food additives such as the xylanase growth hormone (Rasala et al., 2012; Georgianna et al., 2013) and Sep15, a selenium supplement (Hou et al., 2013). Algal-derived oral vaccines were shown to have a long shelf-life and their administration is injection-free. However, as the use of oral vaccines elicits mainly local immunity, their general efficacy must be carefully monitored.

Microalga have been harnessed to express enzymes of interest (Rasala et al., 2010, 2012), as well as for the potential production of biofuels (Georgianna and Mayfield, 2012), although the economical validity of this approach is still not satisfactory. Efforts were also targeted to enhancing the metabolic engineering of algae for enrichment of lipids, although this goal has yet to be reached (Dunahay et al., 1996).

Genetic manipulations could also help in adapting microalgae to different growth conditions. Attempts to convert autotrophic algae into heterotrophs relied on introducing the HUP1 gene form C. kessleri, which encodes for the hexose/ $\mathrm{H}+$ transporter that enables growth in the dark, into V. carteri (Hallmann and Sumper, 1996) and P. tricornutum (Zaslavskaia et al., 2001). Increased hydrogen production (by $150 \%$ ) was obtained when the C. reinhardtii SMT6 mutant, which is a high $\mathrm{H}_{2}$ producing strain, was transformed with the HUP1 gene. This study established the possibility of improving the production of $\mathrm{H}_{2}$ from $\mathrm{H}_{2} \mathrm{O}$ and glucose (Doebbe et al., 2007). Increased hydrogen production was also obtained by a triple knockdown of the light harvesting complex proteins LHCMB1, 2 and 3 by RNAi, which resulted in a $180 \%$ increase in hydrogen production (Oey et al., 2013).

Cartenoid production from $D$. salina and $H$. pluvialis is also of great commercial interest, and is based on the natural production of $\beta$-carotene and astaxanthin. Manipulation of these species is possible, with increased expression of phytoene desaturase resulting in accelerated biosynthesis of astaxanthin. Production of an L504R mutant of phytoene desaturase resulted in increased production of astaxanthin (Steinbrenner and Sandmann, 2006). Furthermore, introducing the C. zofingiensis phytoene synthase, an enzyme that participates in the carotenoid biosynthetic pathway, into C. reinhardtii resulted in increased levels of violaxanthin and lutein (Cordero et al., 2011). These studies emphasize the great potential in manipulating metabolic pathways of high value products by engineering different algal species. Overall, microalgal systems hold great biotechnological potential that will surely be exploited in the future.

\section{Biosafety Considerations}

In the European Union, all genetically modified organisms (GMOs) or their products must receive approval before they can find their way to market. This practice also applies to genetically modified (GM) microorganisms. Thus, a guidance protocol for risk assessment of genetically modified microorganisms was prepared by the European Food Safety Authority (EFSA) in 2006 (http://www.efsa.europa.eu/sites/default/files/scientific output/files/main_documents/374.pdf). The guiding protocols discriminate between the contained use of microalgae and their deliberate release into the environment, as further discussed in an OECD meeting on the Biosafety and Environmental Uses of Micro-Organisms (Wijffels, 2015). Contained use refers to closed conditions in which GM microorganisms are grown, stored, transported, destroyed and disposed, whereas deliberate release refers to GM microorganisms that are released in the environment without restricting their ability to spread. Contained growth can be performed in closed bioreactors (Chaumont, 1993), tubular reactors (Richmond et al., 1993), or polyethylene sleeves (Cohen et al., 1991). These technologies are designed to allow efficient growth and the harvesting of large quantities of microalgal biomass. Examples of deliberate release of GM microorganisms include their use for immunization of fish against various pathogens in open ponds, or when microalgae are employed for cleaning polluted water sources. Risk assessment is usually performed by testing the effects a GM microorganism has on humans, animals, plants and/or the environment, and comparing these effects with those of the conventional nontransformed variant. Risk assessment refers to the toxicity and allergenicity of the GM microorganism or its products, as well as the potential risk of horizontal gene transfer (HGT). To date, there are only a few reports on HGT in microalgae, and these refer mainly to viral-mediated HGT (Monier et al., 2009; Rosenwasser et al., 2014). However, to address this potential risk, even if it is very rare, the use of selection modes based on endogenous metabolic markers that complement a missing activity in a mutant recipient strain would be advantageous over the use of genes that confer resistance to herbicides or antibiotics. Removal of the selection markers is also recommended.

\section{CONCLUSIONS AND FUTURE PERSPECTIVES}

Despite occupying the base of the plant evolutionary tree, algae are distributed worldwide and grow in different climates, under normal and extreme conditions. As such, algae are known to provide a rich repertoire of chemicals and bio-molecules, including those of interest to biotechnological industries. Algae can also be harnessed as an important food source in the frame of aquatic agriculture. Finally, they provide a powerful resource for the production of bio-medical molecules, such as vaccines, antibodies and drugs (Cadoret et al., 2012). Another attractive achievement will enable the introduction of foreign genes that comprise a metabolic pathway that generates a valuable compound. A recent effort to express the complete carotenoid pathway toward enhanced astaxanthin formation was reported for Xanthophyllomyces dendrorhous (Gassel et al., 2014). However, these exciting possibilities are fully dependent on efficient expression of transgenes in microalgae. Indeed, this bottleneck must be addressed, since for occasional cases 
transgene expression had proven to be rather inefficient, for reasons that were not fully understood. Foreign genes can be targeted for expression in the chloroplast either by integration into the chloroplast genome or by their integration in the nuclear genome as fusion genes equipped with targeting signals that direct the import of the protein product into organelles. With regard to the general feasibility of expressing foreign proteins in microalgae, it appears that despite the considerable body of knowledge accumulated, inducing high expression of transgenes is difficult, possibly due to epigenetic mechanisms. Recent studies have made important improvements for overcoming this problem. Expanding the use of microalga for applied and basic research will benefit from the development of better protocols for gene knock-down by RNAi, as well as for successful deletion of specific genes by gene replacement. The recent revolution in genome editing provided by the CRISPR-Cas9 system should be adapted to microalgae in the coming years. Finally, the

\section{REFERENCES}

Adam, Z., Rudella, A., and van Wijk, K. J. (2006). Recent advances in the study of Clp, FtsH and other proteases located in chloroplasts. Curr. Opin. Plant Biol. 9, 234-240. doi: 10.1016/j.pbi.2006.03.010

Afi, L., Metzger, P., Largeau, C., Connan, J., Berkaloff, C., and Rousseau, B. (1996). Bacterial degradation of green microalgae: incubation of Chlorella emersonii and Chlorella vulgaris with Pseudomonas oleovorans and Flavobacterium aquatile. Org. Geochem. 25, 117-130. doi: 10.1016/S0146-6380(96)00113-1

Apt, K. E., Grossman, A., and Kroth-Pancic, P. (1996). Stable nuclear transformation of the diatom Phaeodactylum tricornutum. Mol. Gen. Genet. 252, 572-579.

Arad, S. M., and Levy-Ontman, O. (2010). Red microalgal cell-wall polysaccharides: biotechnological aspects. Curr. Opin. Biotechnol. 21, 358-364. doi: 10.1016/j.copbio.2010.02.008

Baek, K., Lee, Y., Nam, O., Park, S., Sim, S. J., and Jin, E. (2016). Introducing Dunaliella LIP promoter containing light-inducible motifs improves transgenic expression in Chlamydomonas reinhardtii. Biotechnol. J. 11, 384-392. doi: 10.1002/biot.201500269

Bai, L. L., Yin, W. B., Chen, Y. H., Niu, L. L., Sun, Y. R., Zhao, S. M., et al. (2013). A new strategy to produce a defensin: stable production of mutated NP1 in nitrate reductase-deficient Chlorella ellipsoidea. PLoS ONE 8:e54966. doi: 10.1371/journal.pone.0054966

Barahimipour, R., Neupert, J., and Bock, R. (2016). Efficient expression of nuclear transgenes in the green alga Chlamydomonas: synthesis of an HIV antigen and development of a new selectable marker. Plant Mol. Biol. 90, 403-418. doi: 10.1007/s11103-015-0425-8

Barnes, D., Franklin, S., Schultz, J., Henry, R., Brown, E., Coragliotti, A., et al. (2005). Contribution of $5^{\prime}$ - and $3^{\prime}$-untranslated regions of plastid mRNAs to the expression of Chlamydomonas reinhardtii chloroplast genes. Mol. Genet. Genomics 274, 625-636. doi: 10.1007/s00438-005-0055-y

Bateman, J. M., and Purton, S. (2000). Tools for chloroplast transformation in Chlamydomonas: expression vectors and a new dominant selectable marker. Mol. Gen. Genet. 263, 404-410. doi: 10.1007/s0043800 51184

Becker, B., and Marin, B. (2009). Streptophyte algae and the origin of embryophytes. Ann. Bot. 103, 999-1004. doi: 10.1093/aob/mcp044

Ben-Amotz, A., and Avron, M. (1972). Photosynthetic activities of the halophilic alga Dunaliella parva. Plant Physiol. 49, 240-243.

Ben-Amotz, A., and Avron, M. (1983). On the factors which determine massive beta-carotene accumulation in the halotolerant alga Dunaliella bardawil. Plant Physiol. 72, 593-597. doi: 10.1104/pp.72.3.593

Berges, J. (1997). Miniview: algal nitrate reductases. Eur. J. Phycol. 32, 3-8. doi: $10.1080 / 09541449710001719315$ improvement of systems for inducible expression is also of great importance, since this will allow us to control the temporal expression of toxic molecules. Finally, rapid advancements in genome sequencing, now routinely performed for all organisms, will prove instrumental in advancing these goals in the near future.

\section{AUTHOR CONTRIBUTIONS}

LS, NS, and MS all made literature surveys and participated in the writing of the review.

\section{FUNDING}

MS is incumbent of the Myles Thaler Chair in Plant Genetics. NS was supported by the Gazit-Globe fellowship.

Berthold, P., Schmitt, R., and Mages, W. (2002). An engineered Streptomyces hygroscopicus aph 7" gene mediates dominant resistance against hygromycin B in Chlamydomonas reinhardtii. Protist 153, 401-412. doi: 10.1078/14344610260450136

Bingham, S. E., Cox, J. C., and Strem, M. D. (1989). Expression of foreign DNA in Chlamydomonas reinhardtii. FEMS Microbiol. Lett. 53, 77-81. doi: 10.1111/j.1574-6968.1989.tb03600.x

Blaby, I. K., Blaby-Haas, C. E., Tourasse, N., Hom, E. F., Lopez, D., Aksoy, M., et al. (2014). The Chlamydomonas genome project: a decade on. Trends Plant Sci. 19, 672-680. doi: 10.1016/j.tplants.2014.05.008

Blankenship, J. E., and Kindle, K. L. (1992). Expression of chimeric genes by the light-regulated cabII-1 promoter in Chlamydomonas reinhardtii: a cabII-1/nit1 gene functions as a dominant selectable marker in a nit1-nit2-strain. Mol. Cell. Biol. 12, 5268-5279. doi: 10.1128/MCB.12.11.5268

Bock, R. (2015). Engineering plastid genomes: methods, tools, and applications in basic research and biotechnology. Annu. Rev. Plant Biol. 66, 211-241. doi: 10.1146/annurev-arplant-050213-040212

Bocobza, S. E., and Aharoni, A. (2014). Small molecules that interact with RNA: riboswitch based gene control and its involvement in metabolic regulation in plants and algae. Plant J. 79, 693-703. doi: 10.1111/tpj.12540

Bocobza, S. E., Malitsky, S., Araujo, W. L., Nunes-Nesi, A., Meir, S., Shapira, M., et al. (2013). Orchestration of thiamin biosynthesis and central metabolism by combined action of the thiamin pyrophosphate riboswitch and the circadian clock in Arabidopsis. Plant Cell 25, 288-307. doi: 10.1105/tpc.112.106385

Bocobza, S., Adato, A., Mandel, T., Shapira, M., Nudler, E., and Aharoni, A. (2007). Riboswitch-dependent gene regulation and its evolution in the plant kingdom. Gene Dev. 21, 2874-2879. doi: 10.1101/gad.443907

Boger, P., and Sandmann, G. (1998). Carotenoid biosynthesis inhibitor herbicidesmode of action and resistance mechanisms. Pesticide Outlook 9, 25-39.

Borowitzka, M. A. (2013). High-value products from microalgae - their development and commercialisation. J. Appl. Phycol. 25, 743-756. doi: 10.1007/s10811-013-9983-9

Bowler, C., Allen, A. E., Badger, J. H., Grimwood, J., Jabbari, K., Kuo, A., et al. (2008). The Phaeodactylum genome reveals the evolutionary history of diatom genomes. Nature 456, 239-244. doi: 10.1038/nature07410

Boynton, J., Gillham, N., Harris, E., Hosler, J., Johnson, A., Jones, A., et al. (1988). Chloroplast transformation in Chlamydomonas with high velocity microprojectiles. Science 240, 1534-1538. doi: 10.1126/science.2897716

Braun, E., and Aach, H. G. (1975). Enzymatic degradation of the cell wall of Chlorella. Planta 126, 181-185. doi: 10.1007/BF00380622

Breaker, R. R. (2012). Riboswitches and the RNA world. Cold Spring Harb. Perspect. Biol. 4:a003566. doi: 10.1101/cshperspect.a003566

Brown, L. E., Sprecher, S., and Keller, L. (1991). Introduction of exogenous DNA into Chlamydomonas reinhardtii by 
electroporation. Mol. Cell. Biol. 11, 2328-2332. doi: 10.1128/MCB.11. 4.2328

Bruggeman, A. J., Kuehler, D., and Weeks, D. P. (2014). Evaluation of three herbicide resistance genes for use in genetic transformations and for potential crop protection in algae production. Plant Biotechnol. J. 12, 894-902. doi: $10.1111 /$ pbi.12192

Cadoret, J.-P., Garnier, M., and Saint-Jean, B. (2012). "Chapter eight - microalgae, functional genomics and biotechnology," in Advances in Botanical Research, ed P. Gwenaël (Academic Press), 285-341.

Cerutti, H., Johnson, A. M., Gillham, N. W., and Boynton, J. E. (1997a). Epigenetic silencing of a foreign gene in nuclear transformants of Chlamydomonas. Plant Cell 9, 925-945. doi: 10.1105/tpc.9.6.925

Cerutti, H., Johnson, A. M., Gillham, N. W., and Boynton, J. E. (1997b). A eubacterial gene conferring spectinomycin resistance on Chlamydomonas reinhardtii: integration into the nuclear genome and gene expression. Genetics $145,97$.

Cerutti, H., Ma, X., Msanne, J., and Repas, T. (2011). RNA-mediated silencing in algae: biological roles and tools for analysis of gene function. Eukaryot. Cell 10, 1164-1172. doi: 10.1128/EC.05106-11

Cha, T. S., Chen, C.-F., Yee, W., Aziz, A., and Loh, S.-H. (2011). Cinnamic acid, coumarin and vanillin: alternative phenolic compounds for efficient Agrobacterium-mediated transformation of the unicellular green alga, Nannochloropsis sp. J. Microbiol. Methods 84, 430-434. doi: 10.1016/j.mimet.2011.01.005

Cha, T. S., Yee, W., and Aziz, A. (2012). Assessment of factors affecting Agrobacterium-mediated genetic transformation of the unicellular green alga, Chlorella vulgaris. World J. Microbiol. Biotechnol. 28, 1771-1779. doi: 10.1007/s11274-011-0991-0

Chaumont, D. (1993). Biotechnology of algal biomass production: a review of systems for outdoor mass culture. J. Appl. Phycol. 5, 593-604. doi: 10.1007/BF02184638

Chen, H. L., Li, S. S., Huang, R., and Tsai, H. J. (2008). Conditional production of a functional fish growth hormone in the transgenic line of Nannochloropsis oculata (Eustigmatophyceae). J. Phycol. 44, 768-776. doi: 10.1111/j.15298817.2008.00508.X

Chen, Y., Wang, Y. Q., Sun, Y. R., Zhang, L. M., and Li, W. B. (2001). Highly efficient expression of rabbit neutrophil peptide-1 gene in Chlorella ellipsoidea cells. Curr. Genet. 39, 365-370. doi: 10.1007/s002940100205

Cheney, D. P., Mar, E., Saga, N., and van der Meer, J. (1986). Protoplast isolation and cell division in the agar-producing seaweed Gracilaria (Rhodophyta) J. Phycol. 22, 238-243. doi: 10.1111/j.1529-8817.1986.tb04169.x

Cheng, Q., Day, A., Dowson-Day, M., Shen, G.-F., and Dixon, R. (2005). The Klebsiella pneumoniae nitrogenase Fe protein gene (nifH) functionally substitutes for the chlL gene in Chlamydomonas reinhardtii. Biochem. Biophys. Res. Commun. 329, 966-975. doi: 10.1016/j.bbrc.2005.02.064

Cheng, Q., Hallmann, A., Edwards, L., and Miller, S. M. (2006). Characterization of a heat-shock-inducible hsp70 gene of the green alga Volvox carteri. Gene 371, 112-120. doi: 10.1016/j.gene.2005.11.026

Cheng, R., Ma, R., Li, K., Rong, H., Lin, X., Wang, Z., et al. (2012). Agrobacterium tumefaciens mediated transformation of marine microalgae Schizochytrium. Microbiol. Res. 167, 179-186. doi: 10.1016/j.micres.2011.05.003

Chipman, D., Barak, Z., and Schloss, J. V. (1998). Biosynthesis of 2-aceto-2hydroxy acids: acetolactate synthases and acetohydroxyacid synthases. Biochim. Biophys. Acta 1385, 401-419. doi: 10.1016/S0167-4838(98)00083-1

Chow, K.-C., and Tung, W. (1999). Electrotransformation of Chlorella vulgaris. Plant Cell Rep. 18, 778-780. doi: 10.1007/s002990050660

Cohen, E., Koren, A., and Arad, S. (1991). A closed system for outdoor cultivation of microalgae. Biomass Bioenergy 1, 83-88. doi: 10.1016/0961-9534(91)90030-G

Cordero, B. F., Couso, I., León, R., Rodríguez, H., and Vargas, M. Á. (2011). Enhancement of carotenoids biosynthesis in Chlamydomonas reinhardtii by nuclear transformation using a phytoene synthase gene isolated from Chlorella zofingiensis. Appl. Microbiol. Biotechnol. 91, 341-351. doi: 10.1007/s00253-0113262-y

Cui, Y., Qin, S., and Jiang, P. (2014). Chloroplast transformation of Platymonas (Tetraselmis) subcordiformis with the bar gene as selectable marker. PLoS ONE 9:e98607. doi: 10.1371/journal.pone.0098607

Daniell, H., Lee, S. B., Panchal, T., and Wiebe, P. O. (2001). Expression of the native cholera toxin B subunit gene and assembly as functional oligomers in transgenic tobacco chloroplasts. J. Mol. Biol. 311, 1001-1009. doi: 10.1006/jmbi.20 01.4921

Dauvillée, D., Delhaye, S., Gruyer, S., Slomianny, C., Moretz, S. E., d'Hulst, C., et al. (2010). Engineering the chloroplast targeted malarial vaccine antigens in Chlamydomonas starch granules. PLOS ONE 5:e15424. doi: 10.1371/journal.pone.0015424

Dawson, H. N., Burlingame, R., and Cannons, A. C. (1997). Stable transformation of Chlorella: rescue of nitrate reductase-deficient mutants with the nitrate reductase gene. Curr. Microbiol. 35, 356-362. doi: 10.1007/s0028499 00268

Day, A., Debuchy, R., Dillewijn, J., Purton, S., and Rochaix, J. D. (1990). Studies on the maintenance and expression of cloned DNA fragments in the nuclear genome of the green alga Chlamydomonas reinhardtii. Physiol. Plant. 78, 254-260. doi: 10.1111/j.1399-3054.1990.tb02089.x

De Riso, V., Raniello, R., Maumus, F., Rogato, A., Bowler, C., and Falciatore, A. (2009). Gene silencing in the marine diatom Phaeodactylum tricornutum. Nucleic Acids Res. 37, e96. doi: 10.1093/nar/gkp448

Debuchy, R., Purton, S., and Rochaix, J. (1989). The argininosuccinate lyase gene of Chlamydomonas reinhardtii: an important tool for nuclear transformation and for correlating the genetic and molecular maps of the ARG7 locus. EMBO J. 8, 2803.

Diaz, M., Mora, V., Pedrozo, F., Nichela, D., and Baffico, G. (2015). Evaluation of native acidophilic algae species as potential indicators of polycyclic aromatic hydrocarbon (PAH) soil contamination. J. Appl. Phycol. 27, 321-325. doi: 10.1007/s10811-014-0334-2

Diaz-Santos, E., de la Vega, M., Vila, M., Vigara, J., and Leon, R. (2013). Efficiency of different heterologous promoters in the unicellular microalga Chlamydomonas reinhardtii. Biotechnol. Prog. 29, 319-328. doi: $10.1002 /$ btpr.1690

Doebbe, A., Rupprecht, J., Beckmann, J., Mussgnug, J. H., Hallmann, A., Hankamer, B., et al. (2007). Functional integration of the HUP1 hexose symporter gene into the genome of $C$. reinhardtii: Impacts on biological H2 production. J. Biotechnol. 131, 27-33. doi: 10.1016/j.jbiotec.2007. 05.017

Doetsch, N. A., Favreau, M. R., Kuscuoglu, N., Thompson, M. D., and Hallick, R. B. (2001). Chloroplast transformation in Euglena gracilis: splicing of a group III twintron transcribed from a transgenic psbK operon. Curr. Genet. 39, 49-60. doi: 10.1007/s002940000174

Doran, P. M. (2006). Foreign protein degradation and instability in plants and plant tissue cultures. Trends Biotechnol. 24, 426-432. doi: 10.1016/j.tibtech.2006.06.012

Dreesen, I. A. J., Hamri, G. C.-E., and Fussenegger, M. (2010). Heat-stable oral algabased vaccine protects mice from Staphylococcus aureus infection. J. Biotechnol. 145, 273-280. doi: 10.1016/j.jbiotec.2009.12.006

Dunahay, T. (1993). Transformation of Chlamydomonas reinhardtii with silicon carbide whiskers. Biotechniques 15, 452-455, 457-458, 460.

Dunahay, T., Jarvis, E., Dais, S., and Roessler, P. (1996). "Manipulation of microalgal lipid production using genetic engineering," in Seventeenth Symposium on Biotechnology for Fuels and Chemicals, eds C. Wyman and B. Davison (New York, NY: Springer Science+Business Media), 223-231. doi: 10.1007/978-1-4612-0223-3_20

Dunahay, T. G., Jarvis, E. E., and Roessler, P. G. (1995). Genetic transformation of the diatoms Cyclotella cryptica and Navicula saprophila. J. Phycol. 31, 1004-1012. doi: 10.1111/j.0022-3646.1995.01004.x

Eberhard, S., Drapier, D., and Wollman, F. A. (2002). Searching limiting steps in the expression of chloroplast-encoded proteins: relations between gene copy number, transcription, transcript abundance and translation rate in the chloroplast of Chlamydomonas reinhardtii. Plant J. 31, 149-160. doi: 10.1046/j.1365-313X.2002.01340.x

Ebnet, E., Fischer, M., Deininger, W., and Hegemann, P. (1999). Volvoxrhodopsin, a light-regulated sensory photoreceptor of the spheroidal green alga Volvox carteri. Plant Cell 11, 1473-1484. doi: 10.1105/tpc.11.8.1473

Economou, C., Wannathong, T., Szaub, J., and Purton, S. (2014). “A simple, lowcost method for chloroplast transformation of the green alga Chlamydomonas reinhardtii," in Chloroplast Biotechnology, Vol. 1132, ed P. Maliga (New York, NY: Humana Press), 401-411. doi: 10.1007/978-1-62703-995-6_27

Eichler-Stahlberg, A., Weisheit, W., Ruecker, O., and Heitzer, M. (2009). Strategies to facilitate transgene expression in Chlamydomonas 
reinhardtii. Planta 229, 873-883. doi: 10.1007/s00425-0080879-x

Elghabi, Z., Ruf, S., and Bock, R. (2011). Biolistic co-transformation of the nuclear and plastid genomes. Plant J. 67, 941-948. doi: 10.1111/j.1365313X.2011.04631.x

El-Sheekh, M. (1999). Stable transformation of the intact cells of Chlorella kessleri with high velocity microprojectiles. Biol. Plant. 42, 209-216. doi: 10.1023/A:1002104500953

Emadpour, M., Karcher, D., and Bock, R. (2015). Boosting riboswitch efficiency by RNA amplification. Nucleic Acids Res. 43,e66. doi: 10.1093/nar/gkv165

Emanuelsson, O. (2002). Predicting protein subcellular localisation from amino acid sequence information. Brief. Bioinformatics 3, 361-376. doi: 10.1093/bib/3.4.361

Emanuelsson, O., Nielsen, H., Brunak, S., and von Heijne, G. (2000). Predicting subcellular localization of proteins based on their N-terminal amino acid sequence. J. Mol. Biol. 300, 1005-1016. doi: 10.1006/jmbi.20 00.3903

Emanuelsson, O., Nielsen, H., and von Heijne, G. (1999). ChloroP, a neural network-based method for predicting chloroplast transit peptides and their cleavage sites. Protein Sci. 8, 978-984. doi: 10.1110/ps.8.5.978

Fabian, M. R., Sonenberg, N., and Filipowicz, W. (2010). Regulation of mRNA translation and stability by microRNAs. Ann. Rev. Biochem. 79, 351-379. doi: 10.1146/annurev-biochem-060308-103103

Falciatore, A., Casotti, R., Leblanc, C., Abrescia, C., and Bowler, C. (1999). Transformation of nonselectable reporter genes in marine diatoms. Mar. Biotechnol. 1, 239-251. doi: 10.1007/PL00011773

Fernandez, E., Schnell, R., Ranum, L., Hussey, S. C., Silflow, C. D., and Lefebvre, P. A. (1989). Isolation and characterization of the nitrate reductase structural gene of Chlamydomonas reinhardtii. Proc. Natl. Acad. Sci. U.S.A. 86, 6449-6453. doi: 10.1073/pnas.86.17.6449

Ferrante, P., Diener, D. R., Rosenbaum, J. L., and Giuliano, G. (2011). Nickel and low CO2-controlled motility in Chlamydomonas through complementation of a paralyzed flagella mutant with chemically regulated promoters. BMC Plant Biol. 11:22. doi: 10.1186/1471-2229-11-22

Ferris, P. J. (1995). Localization of the nic-7, ac-29 and thi-10 genes within the mating-type locus of Chlamydomonas reinhardtii. Genetics 141, 543-549.

Fischer, H., Robl, I., Sumper, M., and Kröger, N. (1999). Targeting and covalent modification of cell wall and membrane proteins heterologously expressed in the diatom Cylindrotheca fusiformis (Bacillariophyceae). J. Phycol. 35, 113-120. doi: 10.1046/j.1529-8817.1999.3510113.x

Fischer, N., and Rochaix, J.-D. (2001). The flanking regions of PsaD drive efficient gene expression in the nucleus of the green alga Chlamydomonas reinhardtii. Mol. Genet. Genomics 265, 888-894. doi: 10.1007/s004380100485

Fischer, N., Stampacchia, O., Redding, K., and Rochaix, J. D. (1996). Selectable marker recycling in the chloroplast. Mol. Gen. Genet. 251, 373-380. doi: 10.1007/BF02172529

Franklin, S., Ngo, B., Efuet, E., and Mayfield, S. P. (2002). Development of a GFP reporter gene for Chlamydomonas reinhardtii chloroplast. Plant J. 30, 733-744. doi: 10.1046/j.1365-313X.2002.01319.x

Franzen, L. G., Rochaix, J. D., and von Heijne, G. (1990). Chloroplast transit peptides from the green alga Chlamydomonas reinhardtii share features with both mitochondrial and higher plant chloroplast presequences. FEBS Lett. 260, 165-168. doi: 10.1016/0014-5793(90)80094-Y

Fuhrmann, M., Oertel, W., and Hegemann, P. (1999). A synthetic gene coding for the green fluorescent protein (GFP) is a versatile reporter in Chlamydomonas reinhardtii. Plant J. 19, 353-361. doi: 10.1046/j.1365-313X.1999. 00526.x

Gassel, S., Breitenbach, J., and Sandmann, G. (2014). Genetic engineering of the complete carotenoid pathway towards enhanced astaxanthin formation in Xanthophyllomyces dendrorhous starting from a high-yield mutant. Appl. Microbiol. Biotechnol. 98, 345-350. doi: 10.1007/s00253-0135358-Z

Geng, D., Wang, Y., Wang, P., Li, W., and Sun, Y. (2003). Stable expression of hepatitis B surface antigen gene in Dunaliella salina (Chlorophyta). J. Appl. Phycol. 15, 451-456. doi: 10.1023/B:JAPH.0000004298.89183.e5

Geng, D. G., Han, Y., Wang, Y. Q., Wang, P., Zhang, L. M., Li, W. B., et al. (2004). Construction of a system for the stable expression of foreign genes in Dunaliella salina. Acta Bot. Sin. 46, 342-346.
Georgianna, D. R., Hannon, M. J., Marcuschi, M., Wu, S., Botsch, K., Lewis, A. J., et al. (2013). Production of recombinant enzymes in the marine alga Dunaliella tertiolecta. Algal Res. 2, 2-9. doi: 10.1016/j.algal.2012.10.004

Georgianna, D. R., and Mayfield, S. P. (2012). Exploiting diversity and synthetic biology for the production of algal biofuels. Nature 488, 329-335. doi: 10.1038 /nature11479

Ghildiyal, M., and Zamore, P. D. (2009). Small silencing RNAs: an expanding universe. Nat. Rev. Genet. 10, 94-108. doi: 10.1038/nrg2504

Goldschmidt-Clermont, M. (1991). Transgenic expression of aminoglycoside adenine transferase in the chloroplast: a selectable marker of site-directed transformation of Chlamydomonas. Nucleic Acids Res. 19, 4083-4089. doi: 10.1093/nar/19.15.4083

Goldschmidt-Clermont, M., and Rahire, M. (1986). Sequence, evolution and differential expression of the two genes encoding variant small subunits of ribulose bisphosphate carboxylase/oxygenase in Chlamydomonas reinhardtii. J. Mol. Biol. 191, 421-432. doi: 10.1016/0022-2836(86)90137-3

Gregory, J. A., Li, F., Tomosada, L. M., Cox, C. J., Topol, A. B., Vinetz, J. M., et al. (2012). Algae-produced Pfs25 elicits antibodies that inhibit malaria transmission. PLOS ONE 7:e37179. doi: 10.1371/journal.pone.00 37179

Gregory, J. A., Topol, A. B., Doerner, D. Z., and Mayfield, S. (2013). Alga-produced cholera toxin-Pfs25 fusion proteins as oral vaccines. Appl. Environ. Microbiol. 79, 3917-3925. doi: 10.1128/AEM.00714-13

Gruber, A., Rocap, G., Kroth, P. G., Armbrust, E. V., and Mock, T. (2015). Plastid proteome prediction for diatoms and other algae with secondary plastids of the red lineage. Plant J. 81, 519-528. doi: 10.1111/tpj.12734

Grundman, O., Khozin-Goldberg, I., Raveh, D., Cohen, Z., Vyazmensky, M., Boussiba, S., et al. (2012). Cloning, mutagenesis, and characterization of the microalga Parietochloris incisa acetohydroxyacid synthase, and its possible use as an endogenous selection marker. Biotechnol. Bioeng. 109, 2340-2348. doi: 10.1002/bit.24515

Guo, S.-L., Zhao, X.-Q., Tang, Y., Wan, C., Alam, M. A., Ho, S.-H., et al. (2013). Establishment of an efficient genetic transformation system in Scenedesmus obliquus. J. Biotechnol. 163, 61-68. doi: 10.1016/j.jbiotec.2012.10.020

Gutiérrez, C. L., Gimpel, J., Escobar, C., Marshall, S. H., and Henríquez, V. (2012). Chloroplast genetic tool for the green microalgae Haematococcus pluvialis (Chlorophyceae, Volvocales). J. Phycol. 48, 976-983. doi: 10.1111/j.15298817.2012.01178.x

Habib, S. J., Neupert, W., and Rapaport, D. (2007). Analysis and prediction of mitochondrial targeting signals. Methods Cell Biol. 80, 761-781. doi: 10.1016/S0091-679X(06)80035-X

Hagedorn, M., and Carter, V. L. (2015). Seasonal preservation success of the marine Dinoflagellate coral symbiont, Symbiodinium sp. PLoS ONE 10: e0136358. doi: 10.1371/journal.pone.0136358

Hall, L. M., Taylor, K. B., and Jones, D. D. (1993). Expression of a foreign gene in Chlamydomonas reinhardtii. Gene 124, 75-81. doi: 10.1016/03781119(93)90763-S

Hallmann, A. (2007). Algal transgenics and biotechnology. Transgen. Plant J. 1, 81-98. Available online at: http://www.globalsciencebooks.info/Online/ GSBOnline/images/0706/TPJ_1(1)/TPJ_1(1)81-98o.pdf

Hallmann, A., and Rappel, A. (1999). Genetic engineering of the multicellular green alga Volvox: a modified and multiplied bacterial antibiotic resistance gene as a dominant selectable marker. Plant J. 17, 99-109. doi: 10.1046/j.1365313X.1999.00342.X

Hallmann, A., Rappel, A., and Sumper, M. (1997). Gene replacement by homologous recombination in the multicellular green alga Volvox carteri. Proc. Natl. Acad. Sci. U.S.A. 94, 7469-7474. doi: 10.1073/pnas.94. 14.7469

Hallmann, A., and Sumper, M. (1996). The Chlorella hexose/H+ symporter is a useful selectable marker and biochemical reagent when expressed in Volvox. Proc. Natl. Acad. Sci. U.S.A. 93, 669-673. doi: 10.1073/pnas.93.2.669

Hallmann, A., and Wodniok, S. (2006). Swapped green algal promoters: aphVIIIbased gene constructs with Chlamydomonas flanking sequences work as dominant selectable markers in Volvox and vice versa. Plant Cell Rep. 25, 582-591. doi: 10.1007/s00299-006-0121-x

Haring, M. A., and Beck, C. F. (1997). A promoter trap for Chlamydomonas reinhardtii: development of a gene cloning method using $5^{\prime}$ RACE based probes. Plant J. 11, 1341-1348. doi: 10.1046/j.1365-313X.1997.11061341.x 
Harris, E. (2009). Chlamydomonas Sourcebook: Introduction to Chlamydomonas and Its Laboratory Use. San Diego, CA: Academic Press.

Harris, E. H., Burkhart, B. D., Gillham, N. W., and Boynton, J. E. (1989). Antibiotic resistance mutations in the chloroplast $16 \mathrm{~S}$ and 23S rRNA genes of Chlamydomonas reinhardtii: correlation of genetic and physical maps of the chloroplast genome. Genetics 123, 281-292.

Hawkins, R. L., and Nakamura, M. (1999). Expression of human growth hormone by the eukaryotic alga, Chlorella. Curr. Microbiol. 38, 335-341. doi: $10.1007 /$ PL00006813

Hayashi, Y., and Shinozaki, A. (2012). Visualization of microbodies in Chlamydomonas reinhardtii. J. Plant Res. 125, 579-586. doi: 10.1007/s10265011-0469-z

Heitzer, M., Eckert, A., Fuhrmann, M., and Griesbeck, C. (2007). "Influence of codon bias on the expression of foreign genes in microalgae," in Transgenic Microalgae as Green Cell Factories, Vol. 616, eds L. Rosa, G. Aurora, and F. Emilio (New York, NY: Springer), 46-53. doi: 10.1007/978-0-387-75532-8_5

Helliwell, K. E., Scaife, M. A., Sasso, S., Araujo, A. P. U., Purton, S., and Smith, A. G. (2014). Unraveling vitamin B12-responsive gene regulation in algae. Plant Physiol. 165, 388-397. doi: 10.1104/pp.113.234369

Hou, Q., Qiu, S., Liu, Q., Tian, J., Hu, Z., and Ni, J. (2013). Selenoprotein-transgenic Chlamydomonas reinhardtii. Nutrients 5:624. doi: 10.3390/nu5030624

Huang, J., Liu, J., Li, Y., and Chen, F. (2008). Isolation and characterization of the phytoene desaturase gene as a potential selective marker for genetic engineering of the astaxanthin-producing green alga Chlorella zofingiensis (Chlorophyta). J. Phycol. 44, 684-690. doi: 10.1111/j.1529-8817.2008.00511.x

Huang, S., Taylor, N. L., Whelan, J., and Millar, A. H. (2009). Refining the definition of plant mitochondrial presequences through analysis of sorting signals, $\mathrm{N}$ terminal modifications, and cleavage motifs. Plant Physiol. 150, 1272-1285. doi: 10.1104/pp.109.137885

Huesgen, P. F., Schuhmann, H., and Adamska, I. (2009). Deg/HtrA proteases as components of a network for photosystem II quality control in chloroplasts and cyanobacteria. Res. Microbiol. 160, 726-732. doi: 10.1016/j.resmic.2009.08.005

Imam, S. H., and Snell, W. J. (1988). The Chlamydomonas cell wall degrading enzyme, lysin, acts on two substrates within the framework of the wall. J. Cell Biol. 106, 2211-2221. doi: 10.1083/jcb.106.6.2211

Imamura, S., Hagiwara, D., Suzuki, F., Kurano, N., and Harayama, S. (2012). Genetic transformation of Pseudochoricystis ellipsoidea, an aliphatic hydrocarbon-producing green alga. J. Gen. Appl. Microbiol. 58, 1-10. doi: 10.2323/jgam.58.1

Iseki, M., Matsunaga, S., Murakami, A., Ohno, K., Shiga, K., Yoshida, K., et al. (2002). A blue-light-activated adenylyl cyclase mediates photoavoidance in Euglena gracilis. Nature 415, 1047-1051. doi: 10.1038/4151047a

Ishikawa, T., Nishikawa, H., Gao, Y., Sawa, Y., Shibata, H., Yabuta, Y., et al. (2008). The pathway via $\mathrm{D}$-galacturonate/L-galactonate is significant for ascorbate biosynthesis in Euglena gracilis Identification and functional characterization of aldonolactonase. J. Biol. Chem. 283, 31133-31141. doi: 10.1074/jbc.M803930200

Ishikura, K., Takaoka, Y., Kato, K., Sekine, M., Yoshida, K., and Shinmyo, A. (1999). Expression of a foreign gene in Chlamydomonas reinhardtii chloroplast. J. Biosci. Bioeng. 87, 307-314. doi: 10.1016/S1389-1723(99)80037-1

Jaenicke, L., Kuhne, W., Spessert, R., Wahle, U., and Waffenschmidt, S. (1987). Cell-wall lytic enzymes (autolysins) of Chlamydomonas reinhardtii are (hydroxy)proline-specific proteases. Eur. J. Biochem. 170, 485-491. doi: 10.1111/j.1432-1033.1987.tb13725.x

Jakobiak, T., Mages, W., Scharf, B., Babinger, P., Stark, K., and Schmitt, R. (2004). The bacterial paromomycin resistance gene, aphH, as a dominant selectable marker in Volvox carteri. Protist 155, 381-393. doi: 10.1078/1434461042650343

Jarvis, E. E., and Brown, L. M. (1991). Transient expression of firefly luciferase in protoplasts of the green alga Chlorella ellipsoidea. Curr. Genet. 19, 317-321. doi: 10.1007/BF00355062

Jarvis, E. E., Dunahay, T. G., and Brown, L. M. (1992). DNA nucleoside composition and methylation in several species of microalgae. J. Phycol. 28, 356-362. doi: 10.1111/j.0022-3646.1992.00356.x

Jia, Y., Li, S., Allen, G., Feng, S., and Xue, L. (2012). A novel glyceraldehyde3-phosphate dehydrogenase (GAPDH) promoter for expressing transgenes in the halotolerant alga Dunaliella salina. Curr. Microbiol. 64, 506-513. doi: 10.1007/s00284-012-0102-y
Jia, Y., Xue, L., Liu, H., and Li, J. (2009). Characterization of the glyceraldehyde3-phosphate dehydrogenase (GAPDH) gene from the halotolerant alga Dunaliella salina and inhibition of its expression by RNAi. Curr. Microbiol. 58, 426-431. doi: 10.1007/s00284-008-9333-3

Jiang, W., Brueggeman, A. J., Horken, K. M., Plucinak, T. M., and Weeks, D. P. (2014). Successful transient expression of Cas9 and single guide RNA genes in Chlamydomonas reinhardtii. Eukaryot. Cell 13, 1465-1469. doi: 10.1128/EC.00213-14

Jinek, M., Chylinski, K., Fonfara, I., Hauer, M., Doudna, J. A., and Charpentier, E. (2012). A programmable dual-RNA-guided DNA endonuclease in adaptive bacterial immunity. Science 337, 816-821. doi: 10.1126/science. 1225829

Jinkerson, R. E., and Jonikas, M. C. (2015). Molecular techniques to interrogate and edit the Chlamydomonas nuclear genome. Plant J. 82, 393-412. doi: $10.1111 /$ tpj.12801

Jones, C. S., Luong, T., Hannon, M., Tran, M., Gregory, J. A., Shen, Z., et al. (2013). Heterologous expression of the C-terminal antigenic domain of the malaria vaccine candidate $\mathrm{Pfs} 48 / 45$ in the green algae Chlamydomonas reinhardtii. Appl. Microbiol. Biotechnol. 97, 1987-1995. doi: 10.1007/s00253-0124071-7

Kapler, G. M., Coburn, C. M., and Beverley, S. M. (1990). Stable transfection of the human parasite Leishmania major delineates a 30-kilobase region sufficient for extrachromosomal replication and expression. Mol. Cell. Biol. 10, 1084-1094. doi: 10.1128/MCB.10.3.1084

Karas, B. J., Diner, R. E., Lefebvre, S. C., McQuaid, J., Phillips, A. P., Noddings, C. M., et al. (2015). Designer diatom episomes delivered by bacterial conjugation. Nature communications 6, 6925. doi: 10.1038/ncomms7925

Kathiresan, S., Chandrashekar, A., Ravishankar, G. A., and Sarada, R. (2015). Regulation of astaxanthin and its intermediates through cloning and genetic transformation of beta-carotene ketolase in Haematococcus pluvialis. J. Biotechnol. 196-197, 33-41. doi: 10.1016/j.jbiotec.2015.01.006

Kilian, O., and Kroth, P. G. (2005). Identification and characterization of a new conserved motif within the presequence of proteins targeted into complex diatom plastids. Plant J. 41, 175-183. doi: 10.1111/j.1365-313X.2004.02294.X

Kilian, O., Benemann, C. S., Niyogi, K. K., and Vick, B. (2011). High-efficiency homologous recombination in the oil-producing alga Nannochloropsis Sp. Proc. Natl. Acad. Sci. U.S.A. 108, 21265-21269. doi: 10.1073/pnas.1105861108

Kim, D. H., Kim, Y. T., Cho, J. J., Bae, J. H., Hur, S. B., Hwang, I., et al. (2002). Stable integration and functional expression of flounder growth hormone gene in transformed microalga, Chlorella ellipsoidea. Mar. Biotechnol. (New York, NY) 4, 63-73. doi: 10.1007/s1012601-0070-x

Kim, E.-J., and Cerutti, H. (2009). Targeted gene silencing by RNA interference in Chlamydomonas. Methods Cell Biol. 93, 99-110. doi: 10.1016/S0091679X(08)93005-3

Kindle, K. L. (1990). High-frequency nuclear transformation of Chlamydomonas reinhardtii. Proc. Natl. Acad. Sci. U.S.A. 87, 1228-1232. doi: 10.1073/pnas.87.3.1228

Kindle, K. L., Richards, K. L., and Stern, D. B. (1991). Engineering the chloroplast genome: techniques and capabilities for chloroplast transformation in Chlamydomonas reinhardtii. Proc. Natl. Acad. Sci. U.S.A. 88, 1721-1725. doi: 10.1073/pnas.88.5.1721

Kindle, K. L., Schnell, R. A., Fernandez, E., and Lefebvre, P. A. (1989). Stable nuclear transformation of Chlamydomonas using the Chlamydomonas gene for nitrate reductase. J. Cell Biol. 109, 2589-2601. doi: 10.1083/jcb.109.6.2589

Kira, N., Ohnishi, K., Miyagawa-Yamaguchi, A., Kadono, T., and Adachi, M. (2015). Nuclear transformation of the diatom Phaeodactylum tricornutum using PCR-amplified DNA fragments by microparticle bombardment. Mar. Genomics 25, 49-56. doi: 10.1016/j.margen.2015.12.004

Kishore, G. M., and Shah, D. M. (1988). Amino acid biosynthesis inhibitors as herbicides. Annu. Rev. Biochem. 57, 627-663. doi: 10.1146/annurev.bi.57.070188.003211

Koblenz, B., and Lechtreck, K. F. (2005). The NIT1 promoter allows indu cible and reversible silencing of centrin in Chlamydomonas reinhardtii. Eukaryot. Cell 4, 1959-1962. doi: 10.1128/EC.4.11.1959-1962.2005

Kovar, J. L., Zhang, J., Funke, R. P., and Weeks, D. P. (2002). Molecular analysis of the acetolactate synthase gene of Chlamydomonas reinhardtii and development of a genetically engineered gene as a dominant selectable marker 
for genetic transformation. Plant J. 29, 109-117. doi: 10.1046/j.1365-313x.2002. 01193.x

Kuchka, M. R., Goldschmidt-Clermont, M., van Dillewijn, J., and Rochaix, J. D. (1989). Mutation at the Chlamydomonas nuclear NAC2 locus specifically affects stability of the chloroplast $p s b D$ transcript encoding polypeptide D2 of PS II. Cell 58, 869-876. doi: 10.1016/0092-8674(89)90939-2

Kumar, S. V., Misquitta, R. W., Reddy, V. S., Rao, B. J., and Rajam, M. V. (2004). Genetic transformation of the green alga-Chlamydomonas reinhardtii by Agrobacterium tumefaciens. Plant Sci. 166, 731-738. doi: 10.1016/j.plantsci.2003.11.012

Lapidot, M., Raveh, D., Sivan, A., Arad, S. M., and Shapira, M. (1999). Note molecular analysis of AHAS gene of Porphyridium Sp. (Rhodophyta) and of a mutant resistant to sulfometuron methyl. J. Phycol. 35, 1233-1236. doi: 10.1046/j.1529-8817.1999.3561233.x

Lapidot, M., Raveh, D., Sivan, A., Arad, S. M., and Shapira, M. (2002). Stable chloroplast transformation of the unicellular red alga Porphyridium Sp. Plant Physiol. 129, 7-12. doi: 10.1104/pp.011023

Lauersen, K. J., Berger, H., Mussgnug, J. H., and Kruse, O. (2013a). Efficient recombinant protein production and secretion from nuclear transgenes in Chlamydomonas reinhardtii. J. Biotechnol. 167, 101-110. doi: 10.1016/j.jbiotec.2012.10.010

Lauersen, K. J., Huber, I., Wichmann, J., Baier, T., Leiter, A., Gaukel, V., et al. (2015). Investigating the dynamics of recombinant protein secretion from a microalgal host. J. Biotechnol. 215, 62-71. doi: 10.1016/j.jbiotec.2015. 05.001

Lauersen, K. J., Vanderveer, T. L., Berger, H., Kaluza, I., Mussgnug, J. H., Walker, V. K., et al. (2013b). Ice recrystallization inhibition mediated by a nuclearexpressed and -secreted recombinant ice-binding protein in the microalga Chlamydomonas reinhardtii. Appl. Microbiol. Biotechnol. 97, 9763-9772. doi: 10.1007/s00253-013-5226-X

Leon, R., and Fernandez, E. (2007). Nuclear transformation of eukaryotic microalgae: historical overview, achievements and problems. Adv. Exp. Med. Biol. 616, 1-11. doi: 10.1007/978-0-387-75532-8_1

León-Bañares, R., González-Ballester, D., Galván, A., and Fernández, E. (2004). Transgenic microalgae as green cell-factories. Trends Biotechnol. 22, 45-52. doi: 10.1016/j.tibtech.2003.11.003

Lerche, K., and Hallmann, A. (2009). Stable nuclear transformation of Gonium pectorale. BMC Biotechnol. 9:64. doi: 10.1186/1472-6750-9-64

Lerche, K., and Hallmann, A. (2013). Stable nuclear transformation of Eudorina elegans. BMC Biotechnol. 13:11. doi: 10.1186/1472-67 50-13-11

Li, F., Gao, D., and Hu, H. (2014). High-efficiency nuclear transformation of the oleaginous marine Nannochloropsis species using PCR product. Biosci. Biotechnol. Biochem. 78, 812-817. doi: 10.1080/09168451.2014.905184

Li, J., Xue, L., Yan, H., Liu, H., and Liang, J. (2008). Inducible EGFP expression under the control of the nitrate reductase gene promoter in transgenic Dunaliella salina. J. Appl. Phycol. 20, 137-145. doi: 10.1007/s10811-007-9197-0

Li, J., Xue, L., Yan, H., Wang, L., Liu, L., Lu, Y., et al. (2007). The nitrate reductase gene-switch: a system for regulated expression in transformed cells of Dunaliella salina. Gene 403, 132-142. doi: 10.1016/j.gene.2007.08.001

Li, S. S., and Tsai, H. J. (2009). Transgenic microalgae as a non-antibiotic bactericide producer to defend against bacterial pathogen infection in the fish digestive tract. Fish Shellfish Immunol. 26, 316-325. doi: 10.1016/j.fsi.2008.07.004

Li, Z., Hayashimoto, A., and Murai, N. (1992). A sulfonylurea herbicide resistance gene from Arabidopsis thaliana as a new selectable marker for production of fertile transgenic rice plants. Plant Physiol. 100, 662-668. doi: 10.1104/pp.100.2.662

Lin, H., Kwan, A. L., and Dutcher, S. K. (2010). Synthesizing and salvaging NAD: lessons learned from Chlamydomonas reinhardtii. PLoS Genet. 6:e1001105. doi: 10.1371/journal.pgen.1001105

Liu, J., Sun, Z., Gerken, H., Huang, J., Jiang, Y., and Chen, F. (2014). Genetic engineering of the green alga Chlorella zofingiensis: a modified norflurazonresistant phytoene desaturase gene as a dominant selectable marker. Appl. Microbiol. Biotechnol. 98, 5069-5079. doi: 10.1007/s00253-014-5593-y

Liu, W. S., Tang, Y. L., Liu, X. W., and Fang, T. C. (1984). Studies on the preparation and on the properties of sea snail enzymes. Hydrobiologia 116, 319-320. doi: 10.1007/BF00027694
Liu, X., Yu, F., and Rodermel, S. (2010). Arabidopsis chloroplast FtsH, var2 and suppressors of var2 leaf variegation: a review. J. Integr. Plant Biol. 52, 750-761. doi: 10.1111/j.1744-7909.2010.00980.x

Lumbreras, V., Stevens, D. R., and Purton, S. (1998). Efficient foreign gene expression in Chlamydomonas reinhardtii mediated by an endogenous intron. Plant J. 14, 441-447. doi: 10.1046/j.1365-313X.1998.00145.x

Lutz, K. A., Knapp, J. E., and Maliga, P. (2001). Expression of bar in the plastid genome confers herbicide resistance. Plant Physiol. 125, 1585-1590. doi: 10.1104/pp.125.4.1585

Malik, J., Barry, G., and Kishore, G. (1989). The herbicide glyphosate. Biofactors 2, 17-25.

Mandal, M., and Breaker, R. R. (2004). Gene regulation by riboswitches. Nat. Rev. Mol. Cell Biol. 5, 451-463. doi: 10.1038/nrm1403

Manuell, A. L., Beligni, M. V., Elder, J. H., Siefker, D. T., Tran, M., Weber, A., et al. (2007). Robust expression of a bioactive mammalian protein in Chlamydomonas chloroplast. Plant Biotechnol. J. 5, 402-412. doi: 10.1111/j.1467-7652.2007.00249.x

Mayfield, S. P., and Franklin, S. E. (2005). Expression of human antibodies in eukaryotic micro-algae. Vaccine 23, 1828-1832. doi: 10.1016/j.vaccine.2004.11.013

Mayfield, S. P., Franklin, S. E., and Lerner, R. A. (2003). Expression and assembly of a fully active antibody in algae. Proc. Natl. Acad. Sci. U.S.A. 100, 438-442. doi: $10.1073 /$ pnas.0237108100

Mayfield, S. P., and Kindle, K. L. (1990). Stable nuclear transformation of Chlamydomonas reinhardtii by using a C. reinhardtii gene as the selectable marker. Proc. Natl. Acad. Sci. U.S.A. 87, 2087-2091. doi: 10.1073/pnas.87.6.2087

Mayfield, S. P., Manuell, A. L., Chen, S., Wu, J., Tran, M., Siefker, D., et al. (2007). Chlamydomonas reinhardtii chloroplasts as protein factories. Curr. Opin. Biotechnol. 18, 126-133. doi: 10.1016/j.copbio.2007.02.001

Mayfield, S. P., and Schultz, J. (2004). Development of a luciferase reporter gene, luxCt, for Chlamydomonas reinhardtii chloroplast. Plant J. 37, 449-458. doi: 10.1046/j.1365-313X.2003.01965.x

Mazur, B. J., Chui, C. F., and Smith, J. K. (1987). Isolation and characterization of plant genes coding for acetolactate synthase, the target enzyme for two classes of herbicides. Plant Physiol. 85, 1110-1117. doi: 10.1104/pp.85.4.1110

Merchant, S., and Bogorad, L. (1987). The Cu(II)-repressible plastidic cytochrome c. Cloning and sequence of a complementary DNA for the pre-apoprotein. J. Biol. Chem. 262, 9062-9067.

Merchant, S. S., Prochnik, S. E., Vallon, O., Harris, E. H., Karpowicz, S. J., Witman, G. B., et al. (2007). The Chlamydomonas genome reveals the evolution of key animal and plant functions. Science 318, 245-250. doi: 10.1126/science.11 43609

Michelet, L., Lefebvre-Legendre, L., Burr, S. E., Rochaix, J.-D., and GoldschmidtClermont, M. (2011). Enhanced chloroplast transgene expression in a nuclear mutant of Chlamydomonas. Plant Biotechnol. J. 9, 565-574. doi: 10.1111/j.14677652.2010.00564.x

Minoda, A., Sakagami, R., Yagisawa, F., Kuroiwa, T., and Tanaka, K. (2004). Improvement of culture conditions and evidence for nuclear transformation by homologous recombination in a red alga, Cyanidioschyzon merolae 10D. Plant Cell Physiol. 45, 667-671. doi: 10.1093/pcp/pch087

Miyagawa, A., Okami, T., Kira, N., Yamaguchi, H., Ohnishi, K., and Adachi, M. (2009). Research note: High efficiency transformation of the diatom Phaeodactylum tricornutum with a promoter from the diatom Cylindrotheca fusiformis. Phycol. Res. 57, 142-146. doi: 10.1111/j.1440-1835.2009.00531.x

Miyahara, M., Aoi, M., Inoue-Kashino, N., Kashino, Y., and Ifuku, K. (2013). Highly efficient transformation of the diatom Phaeodactylum tricornutum by multi-pulse electroporation. Biosci. Biotechnol. Biochem. 77, 874-876. doi: $10.1271 /$ bbb. 120936

Molnar, A., Bassett, A., Thuenemann, E., Schwach, F., Karkare, S., Ossowski, S., et al. (2009). Highly specific gene silencing by artificial microRNAs in the unicellular alga Chlamydomonas reinhardtii. Plant J. 58, 165-174. doi: 10.1111/j.1365-313X.2008.03767.x

Monier, A., Pagarete, A., de Vargas, C., Allen, M. J., Read, B., Claverie, J. M., et al. (2009). Horizontal gene transfer of an entire metabolic pathway between a eukaryotic alga and its DNA virus. Genome Res. 19, 1441-1449. doi: 10.1101/gr.091686.109

Murray, C., Sutherland, P. W., Phung, M. M., Lester, M. T., Marshall, R. K., and Christeller, J. T. (2002). Expression of biotin-binding proteins, avidin 
and streptavidin, in plant tissues using plant vacuolar targeting sequences. Transgenic Res. 11, 199-214. doi: 10.1023/A:1015237610263

Nakamura, Y., Gojobori, T., and Ikemura, T. (2000). Codon usage tabulated from international DNA sequence databases: status for the year 2000. Nucleic Acids Res. 28, 292-292. doi: 10.1093/nar/28.1.292

Nelson, J., and Lefebvre, P. A. (1995). Targeted disruption of the NIT8 gene in Chlamydomonas reinhardtii. Mol. Cell. Biol. 15, 5762-5769. doi: 10.1128/MCB.15.10.5762

Nelson, J., Savereide, P. B., and Lefebvre, P. A. (1994). The CRY1 gene in Chlamydomonas reinhardtii: structure and use as a dominant selectable marker for nuclear transformation. Mol. Cell. Biol. 14, 4011-4019. doi: 10.1128/MCB.14.6.4011

Neupert, J., and Bock, R. (2009). Designing and using synthetic RNA thermometers for temperature-controlled gene expression in bacteria. Nat. Protoc. 4, 1262-1273. doi: $10.1038 /$ nprot.2009.112

Neupert, J., Karcher, D., and Bock, R. (2009). Generation of Chlamydomonas strains that efficiently express nuclear transgenes. Plant J. 57, 1140-1150. doi: 10.1111/j.1365-313X.2008.03746.x

Newman, S. M., Boynton, J. E., Gillham, N. W., Randolph-Anderson, B. L., Johnson, A. M., and Harris, E. H. (1990). Transformation of chloroplast ribosomal RNA genes in Chlamydomonas: molecular and genetic characterization of integration events. Genetics 126, 875-888.

Newman, S. M., Harris, E. H., Johnson, A. M., Boynton, J. E., and Gillham, N. W. (1992). Nonrandom distribution of chloroplast recombination events in Chlamydomonas Reinhardtii: evidence for a hotspot and an adjacent cold region. Genetics 132, 413-429.

Nickelsen, J., van Dillewijn, J., Rahire, M., and Rochaix, J.-D. (1994). Determinants for stability of the chloroplast psbD RNA are located within its short leader region in Chlamydomonas reinhardtii. EMBO J. 13, 3182.

Niu, Y. F., Yang, Z. K., Zhang, M. H., Zhu, C. C., Yang, W. D., Liu, J. S., et al. (2012). Transformation of diatom Phaeodactylum tricornutum by electroporation and establishment of inducible selection marker. Biotechniques 52, 1-3. doi: $10.2144 / 000113881$

Niu, Y., Zhang, M., Xie, W., Li, J., Gao, Y., Yang, W., et al. (2011). A new inducible expression system in a transformed green alga, Chlorella vulgaris. Genet. Mol. Res. 10, 3427-3434. doi: 10.4238/2011.October.21.1

Nolla-Ardevol, V., Strous, M., and Tegetmeyer, H. E. (2015). Anaerobic digestion of the microalga Spirulina at extreme alkaline conditions: biogas production, metagenome, and metatranscriptome. Front. Microbiol. 6:597. doi: 10.3389/fmicb.2015.00597

Oey, M., Ross, I. L., Stephens, E., Steinbeck, J., Wolf, J., Radzun, K. A., et al. (2013). RNAi knock-down of LHCBM1, 2 and 3 increases photosynthetic H2 production efficiency of the green alga Chlamydomonas reinhardtii. PLoS ONE 8:e61375. doi: 10.1371/journal.pone.0061375

Ohresser, M., Matagne, R. F., and Loppes, R. (1997). Expression of the arylsulphatase reporter gene under the control of the nitl promoter in Chlamydomonas reinhardtii. Curr. Genet. 31, 264-271. doi: $10.1007 / \mathrm{s} 002940050204$

Ossowski, S., Schwab, R., and Weigel, D. (2008). Gene silencing in plants using artificial microRNAs and other small RNAs. Plant J. 53, 674-690. doi: 10.1111/j.1365-313X.2007.03328.x

Ott, K. H., Kwagh, J. G., Stockton, G. W., Sidorov, V., and Kakefuda, G. (1996). Rational molecular design and genetic engineering of herbicide resistant crops by structure modeling and site-directed mutagenesis of acetohydroxyacid synthase. J. Mol. Biol. 263, 359-368. doi: 10.1006/jmbi.1996. 0580

Park, S., Lee, Y., Lee, J. H., and Jin, E. (2013). Expression of the high lightinducible Dunaliella LIP promoter in Chlamydomonas reinhardtii. Planta 238, 1147-1156. doi: 10.1007/s00425-013-1955-4

Patra, K. P., Li, F., Carter, D., Gregory, J. A., Baga, S., Reed, S. G., et al. (2015). Algaproduced malaria transmission-blocking vaccine candidate Pfs 25 formulated with a human use-compatible potent adjuvant induces high-affinity antibodies that block Plasmodium falciparum infection of mosquitoes. Infect. Immun. 83, 1799-1808. doi: 10.1128/IAI.02980-14

Patron, N. J., and Waller, R. F. (2007). Transit peptide diversity and divergence: a global analysis of plastid targeting signals. Bioessays 29, 1048-1058. doi: 10.1002/bies.20638
Popper, Z. A., and Tuohy, M. G. (2010). Beyond the green: understanding the evolutionary puzzle of plant and algal cell walls. Plant Physiol. 153, 373-383. doi: 10.1104/pp.110.158055

Poulsen, N., and Kroger, N. (2005). A new molecular tool for transgenic diatoms: control of mRNA and protein biosynthesis by an inducible promoter-terminator cassette. FEBS J. 272, 3413-3423. doi: 10.1111/j.17424658.2005.04760.x

Poulsen, N., Chesley, P. M., and Kröger, N. (2006). Molecular genetic manipulation of diatom Thalassiosira pseudinana (Bacillariophyceae). J. Phycol. 42, 1059-1065. doi: 10.1111/j.1529-8817.2006.00269.x

Prasad, B., Vadakedath, N., Jeong, H. J., General, T., Cho, M. G., and Lein, W. (2014). Agrobacterium tumefaciens-mediated genetic transformation of haptophytes (Isochrysis species). Appl. Microbiol. Biotechnol. 98, 8629-8639. doi: 10.1007/s00253-014-5900-7

Pratheesh, P. T., Vineetha, M., and Kurup, G. M. (2014). An efficient protocol for the Agrobacterium-mediated genetic transformation of microalga Chlamydomonas reinhardtii. Mol. Biotechnol. 56, 507-515. doi: 10.1007/s12033-013-9720-2

Priyadarshani, I., and Rath, B. (2012). Commercial and industrial applications of micro algae-A review. J. Algal Biomass Utln. 3, 89-100. Available online at: http://jalgalbiomass.com/paper14vol3no4.pdf

Prochnik, S. E., Umen, J., Nedelcu, A. M., Hallmann, A., Miller, S. M., Nishii, I., et al. (2010). Genomic analysis of organismal complexity in the multicellular green alga Volvox carteri. Science 329, 223-226. doi: 10.1126/science.1188800

Przibilla, E., Heiss, S., Johanningmeier, U., and Trebst, A. (1991). Site-specific mutagenesis of the D1 subunit of photosystem II in wild-type Chlamydomonas. Plant Cell 3, 169-174. doi: 10.1105/tpc.3.2.169

Purton, S. (2007). Tools and techniques for chloroplast transformation of Chlamydomonas. Adv. Exp. Med. Biol. 616, 34-45. doi: 10.1007/978-0-38775532-8_4

Purton, S., Szaub, J., Wannathong, T., Young, R., and Economou, C. (2013). Genetic engineering of algal chloroplasts: progress and prospects. Russ. J. Plant Physiol. 60, 491-499. doi: 10.1134/S1021443713040146

Qin, S., Sun, G.-Q., Jiang, P., Zou, L.-H., Wu, Y., and Tseng, C.-K. (1999). “Review of genetic engineering of Laminaria japonica (Laminariales, Phaeophyta) in China," in Proceedings of the Sixteenth International Seaweed Symposium, Vol. 137, Series in Developments in Hydrobiology, eds J. M. Kain, M. T. Brown, and M. Lahaye (New York, NY: Springer), 469-472. doi: 10.1007/978-94-011-44490_56

Quinn, J. M., Eriksson, M., Moseley, J. L., and Merchant, S. (2002). Oxygen deficiency responsive gene expression in Chlamydomonas reinhardtii through a copper-sensing signal transduction pathway. Plant Physiol. 128, 463-471. doi: 10.1104/pp.010694

Quinn, J. M., Kropat, J., and Merchant, S. (2003). Copper response element and Crr1-dependent Ni2+-responsive promoter for induced, reversible gene expression in Chlamydomonas reinhardtii. Eukaryot. Cell 2, 995-1002. doi: 10.1128/EC.2.5.995-1002.2003

Quinn, J. M., and Merchant, S. (1995). Two copper-responsive elements associated with the Chlamydomonas Cyc6 gene function as targets for transcriptional activators. Plant Cell 7, 623-628. doi: 10.1105/tpc.7.5.623

Ramundo, S., Casero, D., Muhlhaus, T., Hemme, D., Sommer, F., Crevecoeur, M., et al. (2014). Conditional depletion of the Chlamydomonas chloroplast $\mathrm{ClpP}$ protease activates nuclear genes involved in autophagy and plastid protein quality control. Plant Cell 26, 2201-2222. doi: 10.1105/tpc.114.124842

Ramundo, S., Rahire, M., Schaad, O., and Rochaix, J.-D. (2013). Repression of essential chloroplast genes reveals new signaling pathways and regulatory feedback loops in Chlamydomonas. Plant Cell 25, 167-186. doi: $10.1105 /$ tpc.112.103051

Rasala, B. A., Barrera, D. J., Ng, J., Plucinak, T. M., Rosenberg, J. N., Weeks, D. P., et al. (2013). Expanding the spectral palette of fluorescent proteins for the green microalga Chlamydomonas reinhardtii. Plant J. 74, 545-556. doi: 10.1111/tpj.12165

Rasala, B. A., Chao, S. S., Pier, M., Barrera, D. J., and Mayfield, S. P. (2014). Enhanced genetic tools for engineering multigene traits into green algae. PLoS ONE 9:e94028. doi: 10.1371/journal.pone.0094028

Rasala, B. A., Lee, P. A., Shen, Z., Briggs, S. P., Mendez, M., and Mayfield, S. P. (2012). Robust expression and secretion of Xylanase1 in Chlamydomonas 
reinhardtii by fusion to a selection gene and processing with the FMDV $2 \mathrm{~A}$ peptide. PLoS ONE 7:e43349. doi: 10.1371/journal.pone.0043349

Rasala, B. A., and Mayfield, S. P. (2014). Photosynthetic biomanufacturing in green algae; production of recombinant proteins for industrial, nutritional, and medical uses. Photosyn. Res. 123, 227-239. doi: 10.1007/s11120-014-9994-7

Rasala, B. A., Muto, M., Lee, P. A., Jager, M., Cardoso, R. M. F., Behnke, C. A., et al. (2010). Production of therapeutic proteins in algae, analysis of expression of seven human proteins in the chloroplast of Chlamydomonas reinhardtii. Plant Biotechnol. J. 8, 719-733. doi: 10.1111/j.1467-7652.2010.00503.x

Reddy, C., Gupta, V., and Jha, B. (2010). "Developments in biotechnology of red algae," in Red Algae in the Genomic Age, eds J. Seckbach and D. J. Chapman (Dordrecht: Springer), 307-341.

Remacle, C., Cline, S., Boutaffala, L., Gabilly, S., Larosa, V., Barbieri, M. R., et al. (2009). The ARG9 gene encodes the plastid-resident $\mathrm{N}$-acetyl ornithine aminotransferase in the green alga Chlamydomonas reinhardtii. Eukaryot. Cell 8, 1460-1463. doi: 10.1128/EC.00108-09

Richmond, A., Boussiba, S., Vonshak, A., and Kopel, R. (1993). A new tubular reactor for mass production of microalgae outdoors. J. Appl. Phycol. 5, 327-332. doi: 10.1007/BF02186235

Rochaix, J.-D., Surzycki, R., and Ramundo, S. (2014). "Tools for regulated gene expression in the chloroplast of Chlamydomonas," in Chloroplast Biotechnology, Vol. 1132, ed P. Maliga (Humana Press), 413-424.

Rohr, J., Sarkar, N., Balenger, S., Jeong, B. R., and Cerutti, H. (2004). Tandem inverted repeat system for selection of effective transgenic RNAi strains in Chlamydomonas. Plant J. 40, 611-621. doi: 10.1111/j.1365-313X.2004. 02227.x

Rosenwasser, S., Mausz, M. A., Schatz, D., Sheyn, U., Malitsky, S., Aharoni, A., et al. (2014). Rewiring host lipid metabolism by large viruses determines the fate of Emiliania huxleyi, a bloom-forming Alga in the Ocean. Plant Cell 26, 2689-2707. doi: $10.1105 /$ tpc.114.125641

Ryan, M. D., King, A., and Thomas, G. P. (1991). Cleavage of foot-and-mouth disease virus polyprotein is mediated by residues located within a 19 amino acid sequence. J. Gen. Virol. 72, 2727-2732. doi: 10.1099/0022-1317-72-11-2727

Sakaue, K., Harada, H., and Matsuda, Y. (2008). Development of gene expression system in a marine diatom using viral promoters of a wide variety of origin. Physiol. Plant 133, 59-67. doi: 10.1111/j.1399-3054.2008.01089.x

Sanger, M., Daubert, S., and Goodman, R. M. (1990). Characteristics of a strong promoter from figwort mosaic virus: comparison with the analogous $35 \mathrm{~S}$ promoter from cauliflower mosaic virus and the regulated mannopine synthase promoter. Plant Mol. Biol. 14, 433-443. doi: 10.1007/ BF00028779

Schiedlmeier, B., Schmitt, R., Muller, W., Kirk, M. M., Gruber, H., Mages, W., et al. (1994). Nuclear transformation of Volvox carteri. Proc. Natl. Acad. Sci. USA. 91, 5080-5084. doi: 10.1073/pnas.91.11.5080

Schmollinger, S., Strenkert, D., and Schroda, M. (2010). An inducible artificial microRNA system for Chlamydomonas reinhardtii confirms a key role for heat shock factor 1 in regulating thermotolerance. Curr. Genet. 56, 383-389. doi: 10.1007/s00294-010-0304-4

Schneider, G., and Fechner, U. (2004). Advances in the prediction of protein targeting signals. Proteomics 4, 1571-1580. doi: 10.1002/pmic.200300786

Schroda, M. (2006). RNA silencing in Chlamydomonas: mechanisms and tools. Curr. Genet. 49, 69-84. doi: 10.1007/s00294-005-0042-1

Schroda, M., Beck, C. F., and Vallon, O. (2002). Sequence elements within an HSP70 promoter counteract transcriptional transgene silencing in Chlamydomonas. Plant J. 31, 445-455. doi: 10.1046/j.1365-313X.2002.01371.x

Schroda, M., Blöcker, D., and Beck, C. F. (2000). The HSP70A promoter as a tool for the improved expression of transgenes in Chlamydomonas. Plant J. 21, 121-131. doi: 10.1046/j.1365-313x.2000.00652.x

Sharon-Gojman, R., Maimon, E., Leu, S., Zarka, A., and Boussiba, S. (2015). Advanced methods for genetic engineering of Haematococcus pluvialis (Chlorophyceae, Volvocales). Algal Res. 10, 8-15. doi: 10.1016/j.algal.2015.03.022

Shimogawara, K., Fujiwara, S., Grossman, A., and Usuda, H. (1998). Highefficiency transformation of Chlamydomonas reinhardtii by electroporation. Genetics 148, 1821-1828.

Sineshchekov, O. A., Jung, K.-H., and Spudich, J. L. (2002). Two rhodopsins mediate phototaxis to low-and high-intensity light in
Chlamydomonas reinhardtii. Proc. Natl. Acad. Sci. U.S.A. 99, 8689-8694. doi: 10.1073/pnas.122243399

Siripornadulsil, S., Dabrowski, K., and Sayre, R. (2007). Microalgal vaccines. Adv. Exp. Med. Biol. 616, 122-128. doi: 10.1007/978-0-387-75532-8_11

Sizova, I., Fuhrmann, M., and Hegemann, P. (2001). A Streptomyces rimosusaphVIII gene coding for a new type phosphotransferase provides stable antibiotic resistance to Chlamydomonas reinhardtii. Gene 277, 221-229. doi: 10.1016/S0378-1119(01)00616-3

Sizova, I., Greiner, A., Awasthi, M., Kateriya, S., and Hegemann, P. (2013). Nuclear gene targeting in Chlamydomonas using engineered zinc-finger nucleases. Plant J. 73, 873-882. doi: 10.1111/tpj.12066

Small, I., Peeters, N., Legeai, F., and Lurin, C. (2004). Predotar: a tool for rapidly screening proteomes for $\mathrm{N}$-terminal targeting sequences. Proteomics 4 , 1581-1590. doi: 10.1002/pmic.200300776

Sodeinde, O. A., and Kindle, K. L. (1993). Homologous recombination in the nuclear genome of Chlamydomonas reinhardtii. Proc. Natl. Acad. Sci. U.S.A. 90, 9199-9203. doi: 10.1073/pnas.90.19.9199

Sontheimer, E. J., and Carthew, R. W. (2005). Silence from within: endogenous siRNAs and miRNAs. Cell 122, 9-12. doi: 10.1016/j.cell.2005. 06.030

Soupene, E., Inwood, W., and Kustu, S. (2004). Lack of the Rhesus protein Rh1 impairs growth of the green alga Chlamydomonas reinhardtii at high CO2. Proc. Natl. Acad. Sci. U.S.A. 101, 7787-7792. doi: 10.1073/pnas.0401809101

Stanne, T., Sjogren, L., Koussevitzky, S., and Clarke, A. (2009). Identification of new protein substrates for the chloroplast ATP-dependent Clp protease supports its constitutive role in Arabidopsis. Biochem. J. 417, 257-268. doi: $10.1042 /$ BJ20081146

Steinbrenner, J., and Sandmann, G. (2006). Transformation of the green alga Haematococcus pluvialis with a phytoene desaturase for accelerated astaxanthin biosynthesis. Appl. Environ. Microbiol. 72, 7477-7484. doi: 10.1128/AEM.01461-06

Stevens, D. R., Purton, S., and Rochaix, J.-D. (1996). The bacterial phleomycin resistance geneble as a dominant selectable marker in Chlamydomonas. Mol. Gen. Genet. 251, 23-30.

Sugiyama, M., Thompson, C. J., Kumagai, T., Suzuki, K., Deblaere, R., Villarroel, R., et al. (1994). Characterisation by molecular cloning of two genes from Streptomyces verticillus encoding resistance to bleomycin. Gene 151, 11-16. doi: 10.1016/0378-1119(94)90626-2

Sun, G., Zhang, X., Sui, Z., and Mao, Y. (2008). Inhibition of pds gene expression via the RNA interference approach in Dunaliella salina (Chlorophyta). Mar. Biotechnol. 10, 219-226. doi: 10.1007/s10126-007-9056-7

Sun, M., Qian, K., Su, N., Chang, H., Liu, J., and Shen, G. (2003). Foot-and-mouth disease virus VP1 protein fused with cholera toxin B subunit expressed in Chlamydomonas reinhardtii chloroplast. Biotechnol. Lett. 25, 1087-1092. doi: 10.1023/A:1024140114505

Sun, X., Ouyang, M., Guo, J., Ma, J., Lu, C., Adam, Z., et al. (2010). The thylakoid protease Deg1 is involved in photosystem-II assembly in Arabidopsis thaliana. Plant J. 62, 240-249. doi: 10.1111/j.1365-313X.2010.04140.x

Sun, Y., Gao, X., Li, Q., Zhang, Q., and Xu, Z. (2006). Functional complementation of a nitrate reductase defective mutant of a green alga Dunaliella viridis by introducing the nitrate reductase gene. Gene 377, 140-149. doi: 10.1016/j.gene.2006.03.018

Sun, Y., Yang, Z., Gao, X., Li, Q., Zhang, Q., and Xu, Z. (2005). Expression of foreign genes in Dunaliella by electroporation. Mol. Biotechnol. 30, 185-192. doi: 10.1385/MB:30:3:185

Surzycki, R., Cournac, L., Peltier, G., and Rochaix, J. D. (2007). Potential for hydrogen production with inducible chloroplast gene expression in Chlamydomonas. Proc. Natl. Acad. Sci. U.S.A. 104, 17548-17553. doi: 10.1073/pnas.0704205104

Surzycki, R., Greenham, K., Kitayama, K., Dibal, F., Wagner, R., Rochaix, J. D., et al. (2009). Factors effecting expression of vaccines in microalgae. Biologicals 37, 133-138. doi: 10.1016/j.biologicals.2009.02.005

Svab, Z., and Maliga, P. (1993). High-frequency plastid transformation in tobacco by selection for a chimeric aadA gene. Proc. Natl. Acad. Sci. U.S.A. 90, 913-917. doi: 10.1073/pnas.90.3.913

Takahashi, F., Yamagata, D., Ishikawa, M., Fukamatsu, Y., Ogura, Y., Kasahara, M., et al. (2007). Aureochrome, a photoreceptor required for photomorphogenesis 
in stramenopiles. Proc. Natl. Acad. Sci. U.S.A. 104, 19625-19630. doi: 10.1073/pnas.0707692104

Takeda, H. (1991). Sugar composition of the cell wall and the taxonomy of Chlorella (Chlorophyceae) 1. J. Phycol. 27, 224-232. doi: 10.1111/j.00223646.1991.00224.x

Tan, C., Qin, S., Zhang, Q., Jiang, P., and Zhao, F. (2005). Establishment of a micro-particle bombardment transformation system for Dunaliella salina. J. Microbiol. 43:361. Available online at: https://www.researchgate.net/profile/ Peng_Jiang17/publication/7614955_Establishment_of_a_micro-particle_bomb ardment_transformation_system_for_Dunaliella_salina._J_Microbiol/links/53 fcd1820cf2364ccc04dbf3.pdf

Tardif, M., Atteia, A., Specht, M., Cogne, G., Rolland, N., Brugiere, S., et al. (2012). PredAlgo: a new subcellular localization prediction tool dedicated to green algae. Mol. Biol. Evol. 29, 3625-3639. doi: 10.1093/molbev/mss178

ten Lohuis, M. R., and Miller, D. J. (1998). Genetic transformation of dinoflagellates (Amphidinium and Symbiodinium): expression of GUS in microalgae using heterologous promoter constructs. Plant J. 13, 427-435. doi: 10.1046/j.1365313X.1998.00040.x

Townsend, J. A., Wright, D. A., Winfrey, R. J., Fu, F., Maeder, M. L., Joung, J. K., et al. (2009). High-frequency modification of plant genes using engineered zinc-finger nucleases. Nature 459, 442-445. doi: 10.1038/nature 07845

Tran, M., Zhou, B., Pettersson, P. L., Gonzalez, M. J., and Mayfield, S. P. (2009). Synthesis and assembly of a full-length human monoclonal antibody in algal chloroplasts. Biotechnol. Bioeng. 104, 663-673. doi: 10.1002/bit. 22446

Varela, J. C., Pereira, H., Vila, M., and Leon, R. (2015). Production of carotenoids by microalgae: achievements and challenges. Photosyn. Res. 125, 423-436. doi: 10.1007/s11120-015-0149-2

Viji, S., Anbazhagi, M., Ponpandian, N., Mangalaraj, D., Jeyanthi, S., Santhanam, P., et al. (2014). Diatom-based label-free optical biosensor for biomolecules. Appl. Biochem. Biotechnol. 174, 1166-1173. doi: 10.1007/s12010-0141040-x

Voinnet, O. (2009). Origin, biogenesis, and activity of plant microRNAs. Cell 136, 669-687. doi: 10.1016/j.cell.2009.01.046

von der Heyde, E. L., Klein, B., Abram, L., and Hallmann, A. (2015). The inducible nitA promoter provides a powerful molecular switch for transgene expression in Volvox carteri. BMC Biotechnol. 15:5. doi: 10.1186/s12896-0150122-3

Wachter, A., Tunc-Ozdemir, M., Grove, B. C., Green, P. J., Shintani, D. K., and Breaker, R. R. (2007). Riboswitch control of gene expression in plants by splicing and alternative $3^{\prime}$ end processing of mRNAs. Plant Cell 19, 3437-3450. doi: 10.1105/tpc.107.053645

Walker, T. L., Becker, D. K., and Collet, C. (2005a). Characterisation of the Dunaliella tertiolecta RbcS genes and their promoter activity in Chlamydomonas reinhardtii. Plant Cell Rep. 23, 727-735. doi: 10.1007/s00299004-0884-x

Walker, T. L., Becker, D. K., Dale, J. L., and Collet, C. (2005b). Towards the development of a nuclear transformation system for Dunaliella tertiolecta. J. Appl. Phycol. 17, 363-368. doi: 10.1007/s10811-005-4783-5

Wang, C., Wang, Y., Su, Q., and Gao, X. (2007). Transient expression of the GUS gene in a unicellular marine green alga, Chlorella sp. MACC/C95, via electroporation. Biotechnol. Bioprocess. Eng. 12, 180-183. doi: 10.1007/BF03028646

Wang, P., Sun, Y., Li, X., Zhang, L., Li, W., and Wang, Y. (2004). Rapid isolation and functional analysis of promoter sequences of the nitrate reductase gene from Chlorella ellipsoidea. J. Appl. Phycol. 16, 11-16. doi: 10.1023/B:JAPH.0000019048.56489.3c

Wang, T. Y., Xue, L. X., Hou, W. H., Yang, B. S., Chai, Y. R., Ji, X. A., et al. (2007). Increased expression of transgene in stably transformed cells of Dunaliella salina by matrix attachment regions. Appl. Microbiol. Biotechnol. 76, 651-657. doi: 10.1007/s00253-007-1040-7

Wang, X., Brandsma, M., Tremblay, R., Maxwell, D., Jevnikar, A., Huner, N., et al. (2008). A novel expression platform for the production of diabetes-associated autoantigen human glutamic acid decarboxylase (hGAD65). BMC Biotechnol. 8:87. doi: $10.1186 / 1472-6750-8-87$

Wijffels, R. H. (2015). "The need and risks of using transgenic microalgae for the production of food, feed, chemicals and fuels," in OECD Biosafety and the Environmental Uses of Micro-Organisms: Conference Proceedings (Paris: OECD Publishing).

Xie, W.-H., Zhu, C.-C., Zhang, N.-S., Li, D.-W., Yang, W.-D., Liu, J.-S., et al. (2014). Construction of novel chloroplast expression vector and development of an efficient transformation system for the diatom Phaeodactylum tricornutum. Mar. Biotechnol. 16, 538-546. doi: 10.1007/s10126-0149570-3

Yamada, T., and Sakaguchi, K. (1982). Comparative studies on Chlorella cell walls: Induction of protoplast formation. Arch. Microbiol. 132, 10-13. doi: 10.1007/BF00690809

Yamano, T., Iguchi, H., and Fukuzawa, H. (2013). Rapid transformation of Chlamydomonas reinhardtii without cell-wall removal. J. Biosci. Bioeng. 115, 691-694. doi: 10.1016/j.jbiosc.2012.12.020

Zaslavskaia, L. A., Lippmeier, J. C., Kroth, P. G., Grossman, A. R., and Apt, K. E. (2000). Transformation of the diatom Phaeodactylum tricornutum (Bacillariophyceae) with a variety of selectable marker and reporter genes. $J$. Phycol. 36, 379-386. doi: 10.1046/j.1529-8817.2000.99164.x

Zaslavskaia, L. A., Lippmeier, J. C., Shih, C., Ehrhardt, D., Grossman, A. R., and Apt, K. E. (2001). Trophic Conversion of an obligate photoautotrophic organism through metabolic engineering. Science 292, 2073-2075. doi: $10.1126 /$ science. 160015

Zhang, C., and Hu, H. (2014). High-efficiency nuclear transformation of the diatom Phaeodactylum tricornutum by electroporation. Marine genomics 16, 63-66. doi: 10.1016/j.margen.2013.10.003

Zhang, R., Patena, W., Armbruster, U., Gang, S. S., Blum, S. R., and Jonikas, M. C. (2014). High-throughput genotyping of green algal mutants reveals random distribution of mutagenic insertion sites and endonucleolytic cleavage of transforming DNA. Plant Cell 26, 1398-1409. doi: 10.1105/tpc.114. 124099

Zhao, T., Wang, W., Bai, X., and Qi, Y. (2009). Gene silencing by artificial microRNAs in Chlamydomonas. Plant J. 58, 157-164. doi: 10.1111/j.1365313X.2008.03758.x

Zheng, B., MacDonald, T. M., Sutinen, S., Hurry, V., and Clarke, A. K. (2006) A nuclear-encoded ClpP subunit of the chloroplast ATP-dependent Clp protease is essential for early development in Arabidopsis thaliana. Planta 224, 1103-1115. doi: 10.1007/s00425-006-0292-2

Zorin, B., Grundman, O., Khozin-Goldberg, I., Leu, S., Shapira, M., Kaye, Y., et al. (2014). Development of a nuclear transformation system for oleaginous green alga Lobosphaera (Parietochloris) incisa and genetic complementation of a mutant strain, deficient in arachidonic acid biosynthesis. Plant J. 58, 157-164. doi: 10.1371/journal.pone. 0105223

Zorin, B., Hegemann, P., and Sizova, I. (2005). Nuclear-gene targeting by using single-stranded DNA avoids illegitimate DNA integration in Chlamydomonas reinhardtii. Eukaryot. Cell 4, 1264-1272. doi: 10.1128/EC.4.7.1264-1272.2005

Conflict of Interest Statement: The authors declare that the review article was written in the absence of any commercial or financial relationships that could be construed as a potential conflict of interest.

The reviewer, KG, and handling Editor declared their shared affiliation, and the handling Editor states that the process nevertheless met the standards of a fair and objective review.

Copyright (c) 2016 Doron, Segal and Shapira. This is an open-access article distributed under the terms of the Creative Commons Attribution License (CC BY). The use, distribution or reproduction in other forums is permitted, provided the original author(s) or licensor are credited and that the original publication in this journal is cited, in accordance with accepted academic practice. No use, distribution or reproduction is permitted which does not comply with these terms. 